\title{
Single Electron Transfer from Dimsyl Anion in the Alkylation of Phenols
}

Samantha Rohe, ${ }^{\mathrm{a}}$ Guillaume Révol, ${ }^{\mathrm{b}}$ Thomas Marmin, ${ }^{\mathrm{b}}$ Daniel Barriault, ${ }^{\mathrm{a}}$ Louis Barriault ${ }^{\mathrm{a} *}$

${ }^{a}$ Centre for Catalysis, Research and Innovation Department of Chemistry and Biomolecular Sciences, University of Ottawa, 10 Marie Curie, Ottawa, Ontario K1N 6N5, Canada

b'OmegaChem, 480 Rue Perreault, Saint-Romuald, Québec G6W 7V6, Canada

Corresponding Author

*Email: louis.barriault@uottawa.ca

\section{Table of Content}

1. Full Optimization $\quad$ S2

2. 2,2', 6, 6'-tetrachloro-1,1'-biphenyl byproduct $\quad$ S4

3. Solvent Screen for Sulphoxide Scope S4

4. Unsuccessful Substartes

5. Isomerization of 2-propenylphenol Under Standard Conditions

6. Kinetic Isotope Effect (KIE) Competitive Experiments S8

7. ${ }^{1} \mathrm{H}$ and ${ }^{13} \mathrm{C}$ NMR Spectra $\quad$ S10 


\section{Full Optimization}

Table S1. Optimization of the reaction conditions<smiles>Cc1ccc(Br)cc1[18OH]</smiles>

$1 \mathrm{a}$

1 equiv.<smiles>Clc1cccc(Cl)c1I</smiles>

2

$x$ equiv.

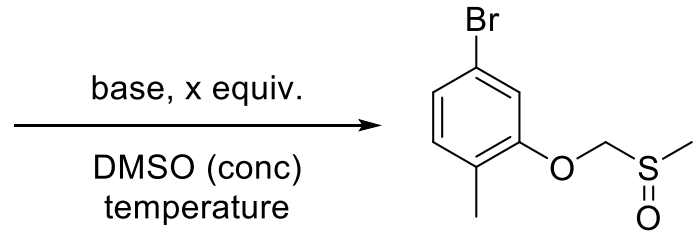

$3 a$

\begin{tabular}{|c|c|c|c|c|c|c|c|}
\hline Entry & $\begin{array}{c}\text { Iodoarene } \\
\text { (equiv) }\end{array}$ & $\begin{array}{c}\text { DMSO } \\
\text { conc. }(\mathbf{M})\end{array}$ & $\begin{array}{l}\text { Base } \\
\text { (equiv) }\end{array}$ & $\begin{array}{c}\text { Temp } \\
\left({ }^{\circ} \mathrm{C}\right)\end{array}$ & t (h) & conversion of sm & $\begin{array}{c}\% \\
\text { yield }\end{array}$ \\
\hline 1 & $2(1.1)$ & 0.1 & $\begin{array}{c}\mathrm{K}_{2} \mathrm{CO}_{3} \\
(2.2)\end{array}$ & 135 & 16 & 92 & $\begin{array}{c}67 \\
\left(58^{\mathrm{i}}\right)\end{array}$ \\
\hline 2 & $2(1.1)$ & 0.1 & $\begin{array}{c}\mathrm{K}_{2} \mathrm{CO}_{3} \\
(2.2)\end{array}$ & 160 & 16 & 100 & 54 \\
\hline 3 & $2(1.1)$ & 0.1 & $\begin{array}{c}\mathrm{K}_{2} \mathrm{CO}_{3} \\
(2.2)\end{array}$ & 110 & 16 & 100 & 37 \\
\hline 4 & $2(1.1)$ & 0.1 & $\begin{array}{c}\mathrm{K}_{2} \mathrm{CO}_{3} \\
(2.2)\end{array}$ & 70 & 16 & 38 & $<5$ \\
\hline 5 & $2(1.1)$ & 0.1 & $\begin{array}{c}\mathrm{K}_{2} \mathrm{CO}_{3} \\
(2.2)\end{array}$ & 135 & 66 & 100 & 57 \\
\hline 6 & $2(1.1)$ & 0.1 & $\begin{array}{c}\mathrm{K}_{2} \mathrm{CO}_{3} \\
(2.2)\end{array}$ & r.t. & 32 & 100 & 0 \\
\hline 7 & $2(1.1)$ & 0.1 & none & 135 & 16 & degradation & 0 \\
\hline 8 & $2(1.1)$ & 0.1 & $\begin{array}{c}\mathrm{Na}_{2} \mathrm{CO}_{3} \\
(2.2)\end{array}$ & 135 & 16 & 100 & trace \\
\hline 9 & $2(1.1)$ & 0.1 & $\begin{array}{c}\mathrm{Cs}_{2} \mathrm{CO}_{3} \\
(2.2)\end{array}$ & 135 & 16 & 100 & 54 \\
\hline 10 & $2(1.1)$ & 0.1 & $\begin{array}{c}\mathrm{Cs}_{2} \mathrm{CO}_{3} \\
(2.2)\end{array}$ & 70 & 16 & 70 & 32 \\
\hline 11 & $2(1.1)$ & 0.1 & $\begin{array}{c}\mathrm{K}_{2} \mathrm{CO}_{3} \\
(1.1)\end{array}$ & 135 & 16 & 100 & 79 \\
\hline 12 & $2(1.1)$ & 0.1 & $\begin{array}{c}\mathrm{K}_{2} \mathrm{CO}_{3} \\
(3.3)\end{array}$ & 135 & 16 & $>95 \%$ & 31 \\
\hline 13 & $2(1.1)$ & 0.1 & $\begin{array}{c}\mathrm{K}_{2} \mathrm{CO}_{3} \\
(0.5)\end{array}$ & 135 & 16 & $\begin{array}{l}\text { Recovered } 80 \% \\
\text { phenol }\end{array}$ & 0 \\
\hline 14 & $2(1.5)$ & 0.1 & $\begin{array}{c}\mathrm{K}_{2} \mathrm{CO}_{3} \\
(2.2)\end{array}$ & 135 & 16 & 100 & $\begin{array}{c}96 \\
\left(70^{i}\right)\end{array}$ \\
\hline 15 & $2(0.5)$ & 0.1 & $\begin{array}{c}\mathrm{K}_{2} \mathrm{CO}_{3} \\
(2.2)\end{array}$ & 135 & 16 & $>95$ & 32 \\
\hline 16 & none & 0.1 & $\begin{array}{c}\mathrm{K}_{2} \mathrm{CO}_{3} \\
(2.2)\end{array}$ & 135 & 16 & 94 & 0 \\
\hline 17 & $\begin{array}{c}\text { 1-chloro-2- } \\
\text { iodobenzene } \\
\quad(1.5)\end{array}$ & 0.1 & $\begin{array}{c}\mathrm{K}_{2} \mathrm{CO}_{3} \\
(2.2)\end{array}$ & 135 & 16 & $\begin{array}{l}\text { Degradation of } \\
\text { phenol, recovered } \\
\text { arene }\end{array}$ & 0 \\
\hline
\end{tabular}




\begin{tabular}{|c|c|c|c|c|c|c|c|}
\hline 18 & $\begin{array}{c}\text { Iodobenzene } \\
(1.5)\end{array}$ & 0.1 & $\begin{array}{c}\mathrm{K}_{2} \mathrm{CO}_{3} \\
(2.2)\end{array}$ & 135 & 16 & $\begin{array}{c}\text { Degradation of } \\
\text { phenol, recovered } \\
\text { haloarene }\end{array}$ & 0 \\
\hline 19 & $\begin{array}{c}\text { Trichlorobenzene } \\
\text { (1.5) }\end{array}$ & 0.1 & $\begin{array}{c}\mathrm{K}_{2} \mathrm{CO}_{3} \\
(2.2)\end{array}$ & 135 & 16 & $\begin{array}{c}\text { Degradation of } \\
\text { phenol, recovered } \\
\text { haloarene }\end{array}$ & 0 \\
\hline 20 & $2(1.5)$ & 0.5 & $\begin{array}{c}\mathrm{K}_{2} \mathrm{CO}_{3} \\
(2.2)\end{array}$ & 135 & 16 & 100 & 26 \\
\hline 21 & $2(1.5)$ & 0.2 & $\begin{array}{c}\mathrm{K}_{2} \mathrm{CO}_{3} \\
(2.2)\end{array}$ & 135 & 16 & 100 & 0 \\
\hline 22 & $2(1.5)$ & 0.05 & $\begin{array}{c}\mathrm{K}_{2} \mathrm{CO}_{3} \\
(2.2)\end{array}$ & 135 & 16 & 100 & 84 \\
\hline 23 & $2(1.5)$ & 0.025 & $\begin{array}{c}\mathrm{K}_{2} \mathrm{CO}_{3} \\
(2.2)\end{array}$ & 135 & 16 & 100 & 62 \\
\hline 24 & $2(1.1)$ & 0.1 & $\begin{array}{c}\mathrm{K}_{2} \mathrm{CO}_{3} \\
(2.2)\end{array}$ & 135 & 6 & 84 & 30 \\
\hline 25 & $2(1.5)$ & 0.1 & $\begin{array}{c}\mathrm{KO} t \mathrm{Bu} \\
(3)\end{array}$ & 135 & 16 & decomposition & 6 \\
\hline 26 & $2(1.5)$ & 0.1 & $\begin{array}{c}\mathrm{KO} t \mathrm{Bu} \\
(0.75)\end{array}$ & 135 & 16 & 100 & 35 \\
\hline $27^{\mathrm{a}}$ & $2(1.5)$ & 0.1 & $\begin{array}{c}\mathrm{K}_{2} \mathrm{CO}_{3} \\
(2.2)\end{array}$ & 135 & 16 & degradation & 0 \\
\hline $28^{\mathrm{b}}$ & $2(1.5)$ & 0.1 & $\begin{array}{c}\mathrm{K}_{2} \mathrm{CO}_{3} \\
(2.2)\end{array}$ & 135 & 16 & 100 & 64 \\
\hline $29^{c}$ & $2(1.5)$ & 0.1 & $\begin{array}{c}\mathrm{K}_{2} \mathrm{CO}_{3} \\
(2.2)\end{array}$ & 135 & 16 & 100 & 44 \\
\hline $30^{\mathrm{d}}$ & $2(1.5)$ & 0.1 & $\begin{array}{c}\mathrm{K}_{2} \mathrm{CO}_{3} \\
(2.2)\end{array}$ & 135 & 16 & 100 & 79 \\
\hline $31^{\mathrm{e}}$ & $2(1.5)$ & 0.1 & $\begin{array}{c}\mathrm{K}_{2} \mathrm{CO}_{3} \\
(2.2)\end{array}$ & 135 & 16 & 100 & 60 \\
\hline $32^{f}$ & $2(1.5)$ & 0.1 & $\begin{array}{c}\mathrm{K}_{2} \mathrm{CO}_{3} \\
(2.2)\end{array}$ & r.t. & 16 & $\begin{array}{c}\text { Recovered } 22 \% \\
\text { phenol, } 88 \% \\
\text { haloarene }\end{array}$ & 0 \\
\hline $33^{g}$ & $2(1.5)$ & 0.1 & $\begin{array}{c}\mathrm{K}_{2} \mathrm{CO}_{3} \\
(2.2)\end{array}$ & r.t. & 16 & $\begin{array}{l}\text { Recovered } 25 \% \\
\text { phenol }\end{array}$ & 0 \\
\hline $34^{\mathrm{h}}$ & $2(1.5)$ & 0.1 & $\begin{array}{c}\mathrm{K}_{2} \mathrm{CO}_{3} \\
(1.1)\end{array}$ & 135 & 16 & Recovered $11 \%$ BHT & trace \\
\hline
\end{tabular}

All yields are by comparison to an NMR standard (phenyltrimethylsilane) unless otherwise noted.

${ }^{\mathrm{i}}=$ isolated yield. ${ }^{\mathrm{a}}$ reaction run with 2 equivalents of TEMPO. ${ }^{\mathrm{b}}$ solvent 50:50 toluene:DMSO. ${ }^{\mathrm{c}}$ reaction degassed and run under Ar atmosphere. ${ }^{\mathrm{d}}$ reaction run on $0.5 \mathrm{~g}$ of phenol. ${ }^{\mathrm{e}}$ reaction run on $1 \mathrm{~g}$ of phenol. ${ }^{\mathrm{f}}$ reaction run at r.t. irradiated under blue LED for $16 \mathrm{~h}$ WITHOUT degassing solvent. ${ }^{\mathrm{g}}$ reaction run at r.t. irradiated under blue LED for $16 \mathrm{~h}$ with DEGASSED solvent under Ar. ${ }^{\mathrm{h}}$ reaction run with 2 equivalents of BHT. 


\section{2,2',6,6'-tetrachloro-1,1'-biphenyl Byproduct}
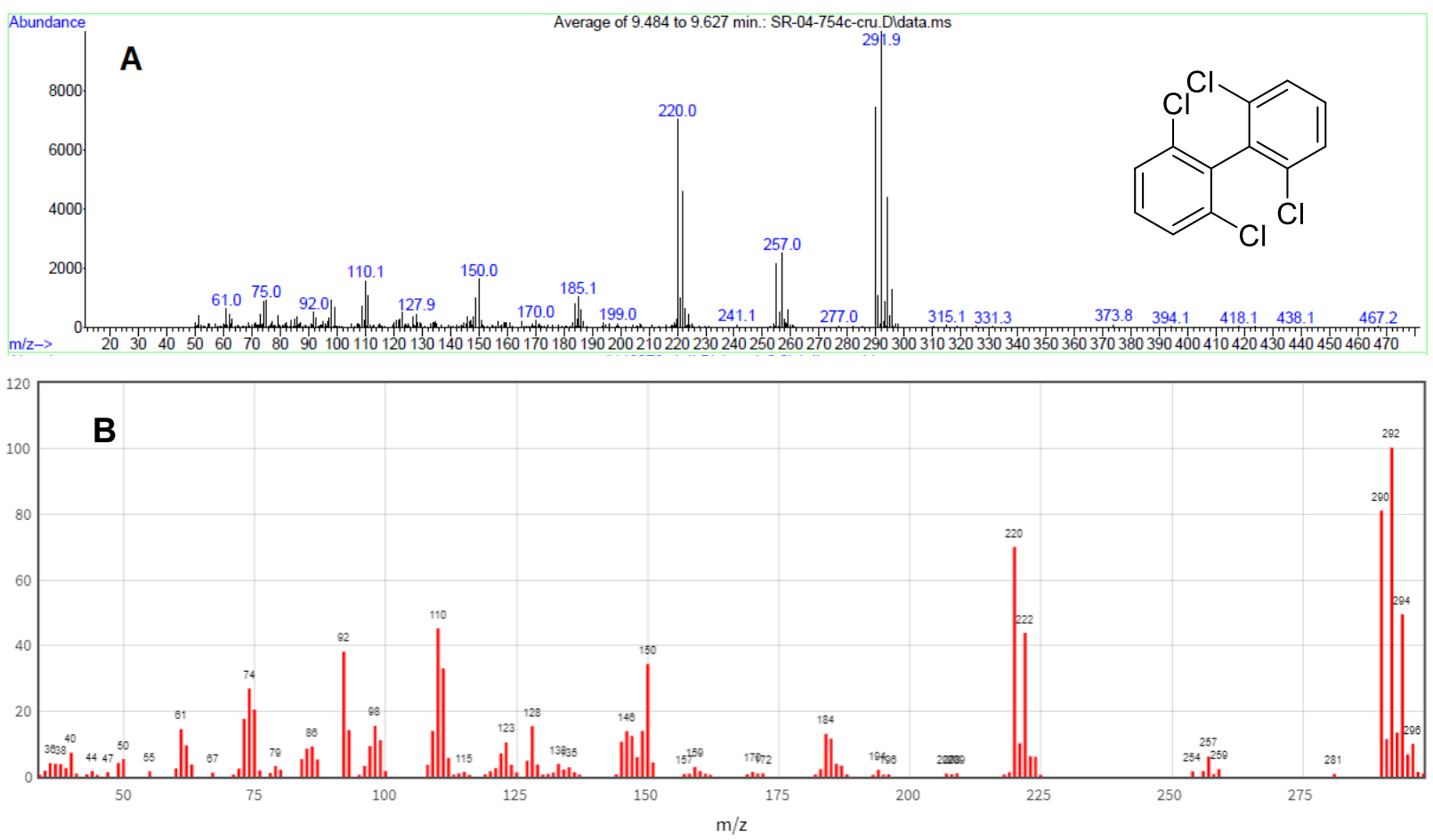

Figure S1. A) Fragmentation pattern for byproduct observed in most of the scope reactions. B) NIST Mass Spectral Database Webbook EI mass spectrum for 2,2',6,6'-tetrachloro-1,1'-biphenyl. Online record can be found at https://webbook.nist.gov/cgi/inchi/InChI\%3D1S/C12H6Cl4/c13-7-3-1-4-8(14)11(7)129(15)5-2-6-10(12)16/h1-6H.

\section{Solvent Screen for Sulfoxide Scope}

Table S2.

\begin{tabular}{lll}
\hline Cosolvent (vol, $\mathbf{~ m L})$ & Sulfoxide (vol, $\mathbf{~ m L})$ & Yield $^{(\%)} \mathbf{q}^{\mathbf{a}}$ \\
\hline None & Phenyl methyl sulfoxide (3) & $<15^{\mathrm{b}}$ \\
Benzene (1.5) & Dimethyl sulfoxide (1.5) & 65 \\
Benzene (1.5) & Phenyl methyl sulfoxide (1.5) & $<15$ \\
Toluene (1.5) & Phenyl methyl sulfoxide (1.5) & Trace \\
o-xylene (1.5) & Phenyl methyl sulfoxide (1.5) & Trace \\
Mesitylene (1.5) & Phenyl methyl sulfoxide (1.5) & Trace \\
None & Diethyl sulfoxide (3) & Complex \\
& & mixture \\
Benzene (1.5) & Diethyl sulfoxide (1.5) & Trace \\
\hline
\end{tabular}

${ }^{\mathrm{a}}$ NMR Yield with phenyltrimethylsilane.

${ }^{\mathrm{b}}$ Product inseparable from phenyl methyl sulfoxide starting material 


\section{Unsuccessful Substrates}

\section{Other Nucleophiles:}<smiles>Sc1ccccc1</smiles><smiles>[R]Nc1ccccc1</smiles><smiles>OC1CCCCC1O</smiles><smiles>OCC(F)(F)C(F)(F)CO</smiles>

Phenols:<smiles>C=CCc1ccccc1O</smiles><smiles>Oc1cccnc1</smiles>

$\mathrm{HO}$<smiles>Cc1ccc(C(C)(C)c2ccc(O)cc2)cc1</smiles>

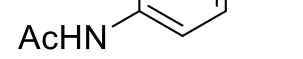<smiles>Oc1ccccc1O</smiles><smiles>O=C(O)c1ccc(O)c([N+](=O)[O-])c1</smiles><smiles>O=C(O)c1ccc(O)c([N+](=O)[O-])c1</smiles><smiles>Oc1cccc2c1ccn2[123I]</smiles><smiles>OCc1ccc(O)cc1</smiles><smiles>Oc1ccc(S)cc1</smiles><smiles>Oc1ccc(O)cc1</smiles>

Figure S2. Substrates attempted under standard reaction conditions that resulted in $<15 \%$ of product or recovery/degradation of starting material. 
5. Isomerization of 2-propenylphenol Under Standard Conditions

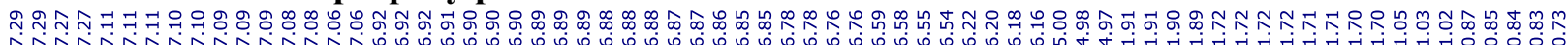

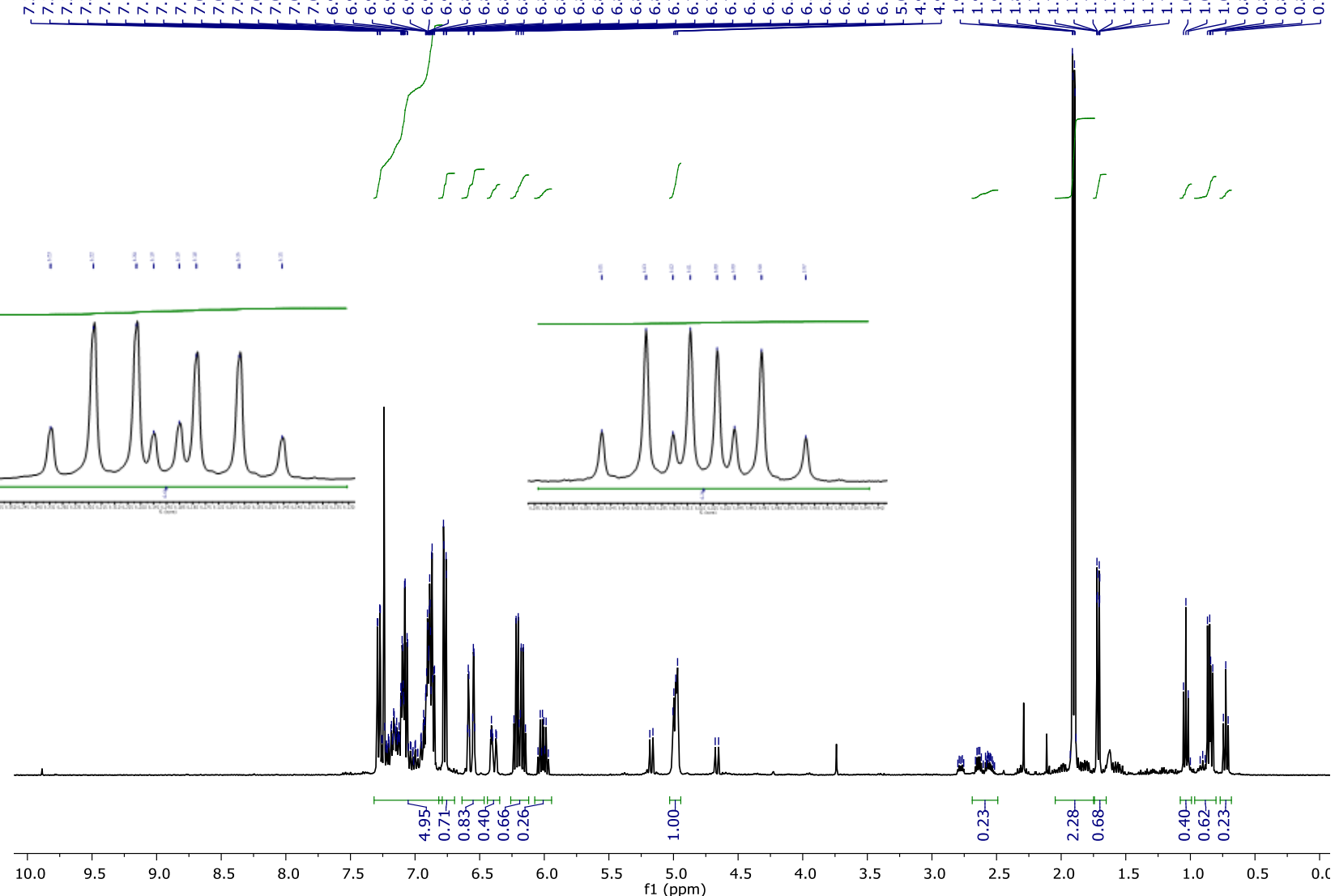

Figure S3. ${ }^{1} \mathrm{H}$ NMR spectrum of starting material 1q.

The insert regions within the above spectrum detail the peaks used to calculate ratio of $E: Z$ olefins in the parent phenol substrate. These peaks represent the same proton in the $E$ and $Z$ configurations (left and right respectively). Raw integration of each region was expressed as a percentage of the total giving a ratio of $72: 28 \mathrm{E}: Z$. 


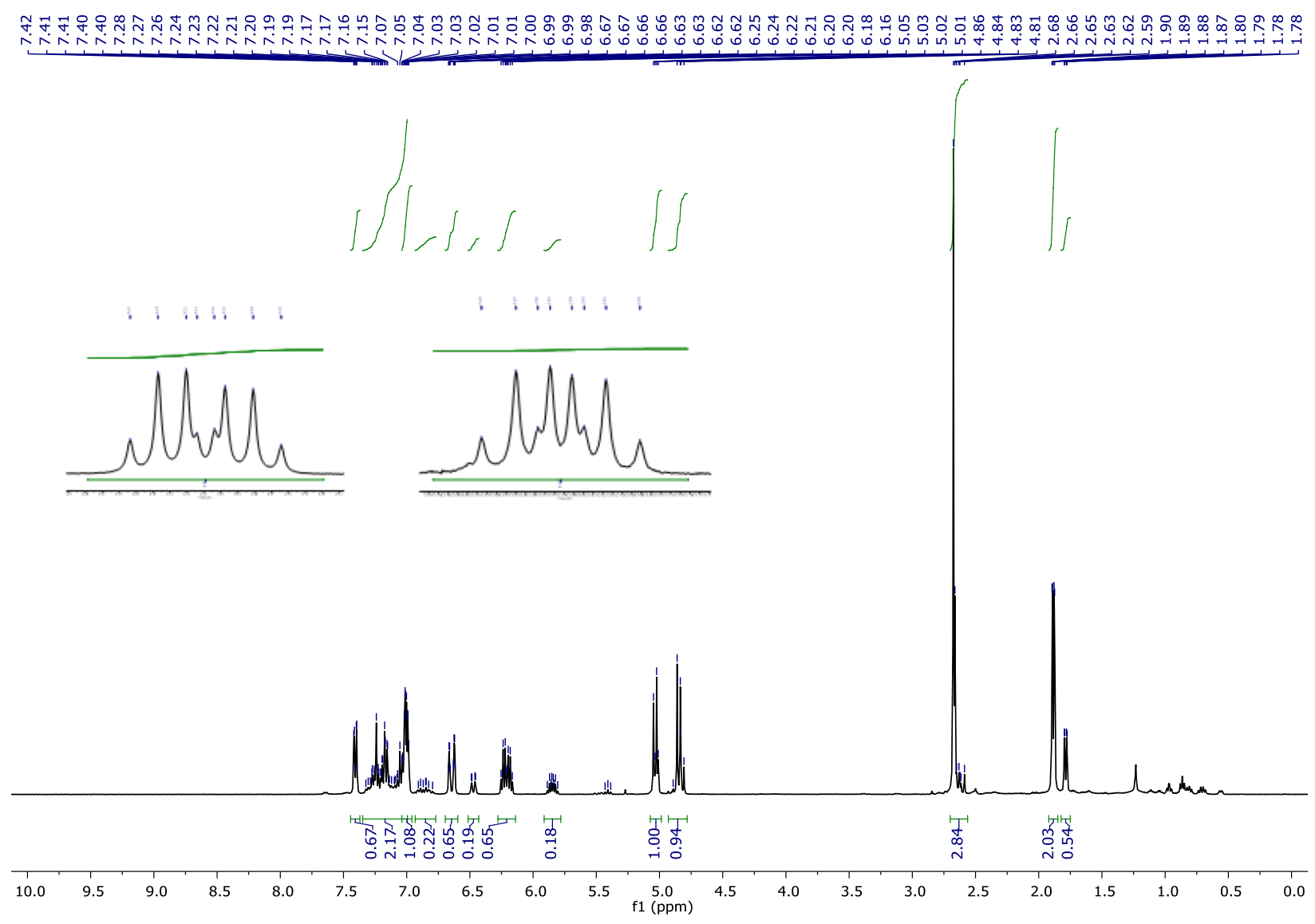

Figure S4. ${ }^{1} \mathrm{H}$ NMR spectrum of product 3q.

The insert regions within the above spectrum detail the peaks used to calculate ratio of $E: Z$ olefins in the alkylated phenol product 3q. These peaks represent the same proton in the $E$ and $Z$ configurations (left and right respectively). Raw integration of each region was expressed as a percentage of the total giving a ratio of $78: 22 \mathrm{E}: Z$. 


\section{Kinetic Isotope Effect (KIE) Competition Experiments}

Deuterium-labeling experiments were performed as per GP1 with either pure DMSO-d6 or a 1:1 mixture of DMSO:DMSO-d6 as solvent. KIE data was obtained by analyzing the ratio between deuterated and proteated products following isolation of product (see ${ }^{1} \mathrm{H}$ NMR spectrum below). Most notably, it was observed that the deuterium incorporation in the reaction with 1:1 DMSO:DMSO-d6 was asymmetrical with respect to the $\alpha$-sulfoxide positions $(10 \%$ and $24 \%$ deuterium incorporation at the etheric position, and $32 \%$ deuterium incorporation at the terminal position). This data suggests that any KIE's obtained with this method will be unreliable due to facile deuterium-protium exchange at the $\alpha$-sulfoxide positions.

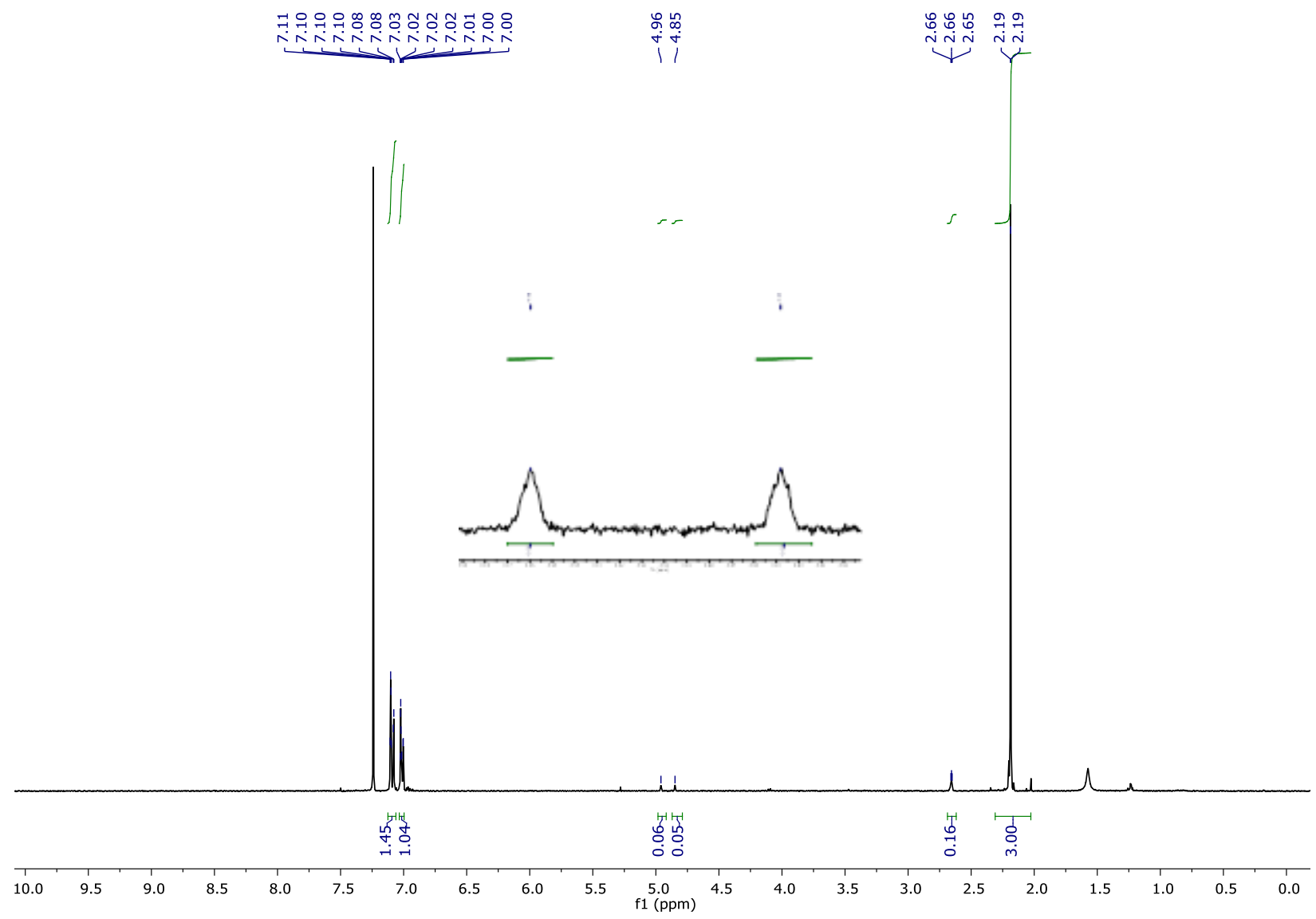

Figure S5. ${ }^{1} \mathrm{H}$ NMR spectrum of product d-3a

The insert region within the above spectrum details two peaks used to calculate ratio of etheric $\alpha$-sulfoxide deuterium incorporation in product d-3a. The singlet at 2.66 was also used to calculate terminal $\alpha$-sulfoxide deuterium incorporation. Solvent used for this experiment was 100\% DMSO-d6. 


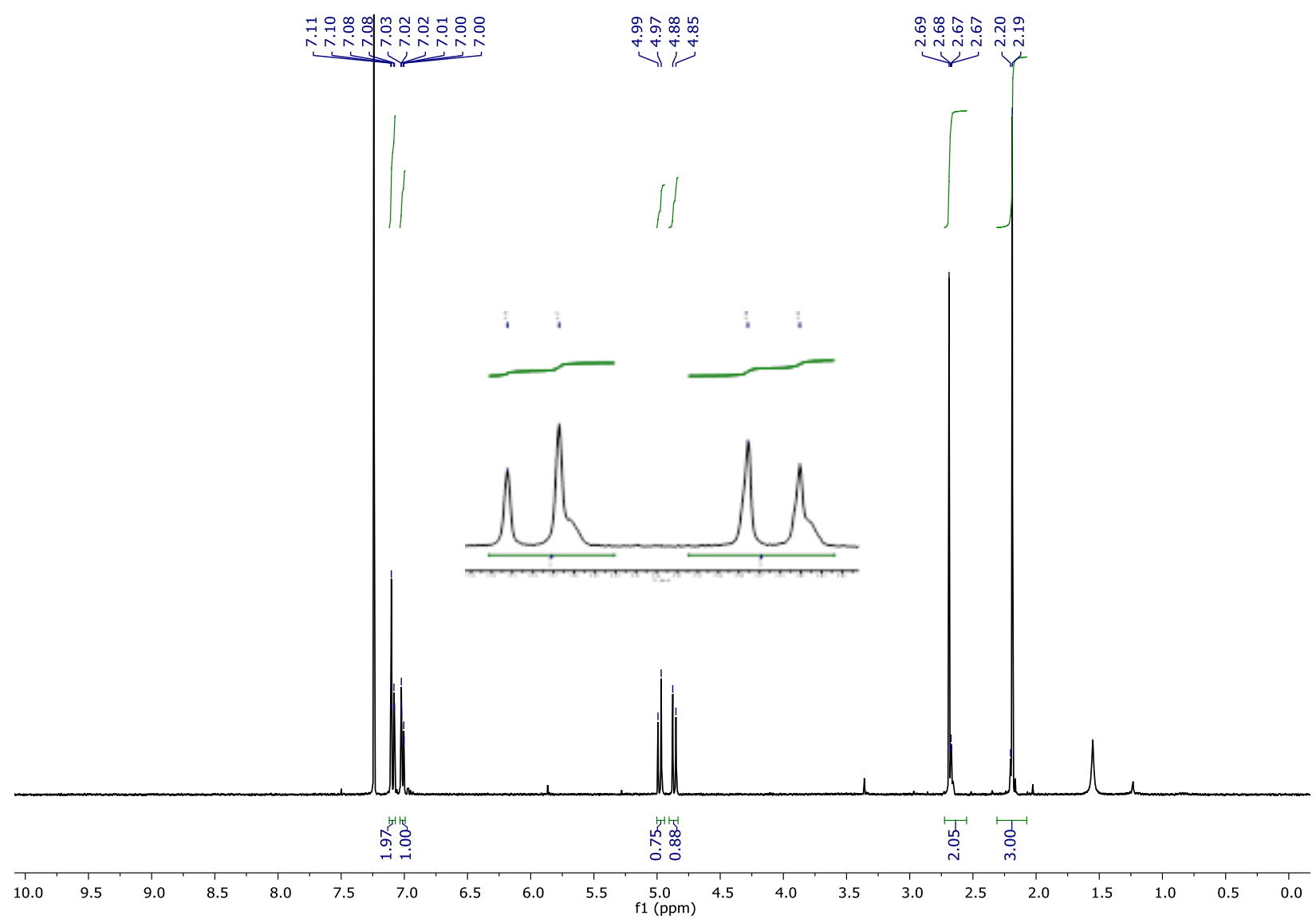

Figure S6. ${ }^{1} \mathrm{H}$ NMR spectrum of mixed deuterated product 3a and $\mathbf{d - 3 a}$

The insert region within the above spectrum details two peaks used to calculate ratio of etheric $\alpha$-sulfoxide deuterium incorporation in product d-3a. The large singlet at 2.66 was also used to calculate terminal $\alpha$ sulfoxide deuterium incorporation. Solvent used for this experiment was 1:1 DMSO:DMSO-d6. 
7. NMR Spectra

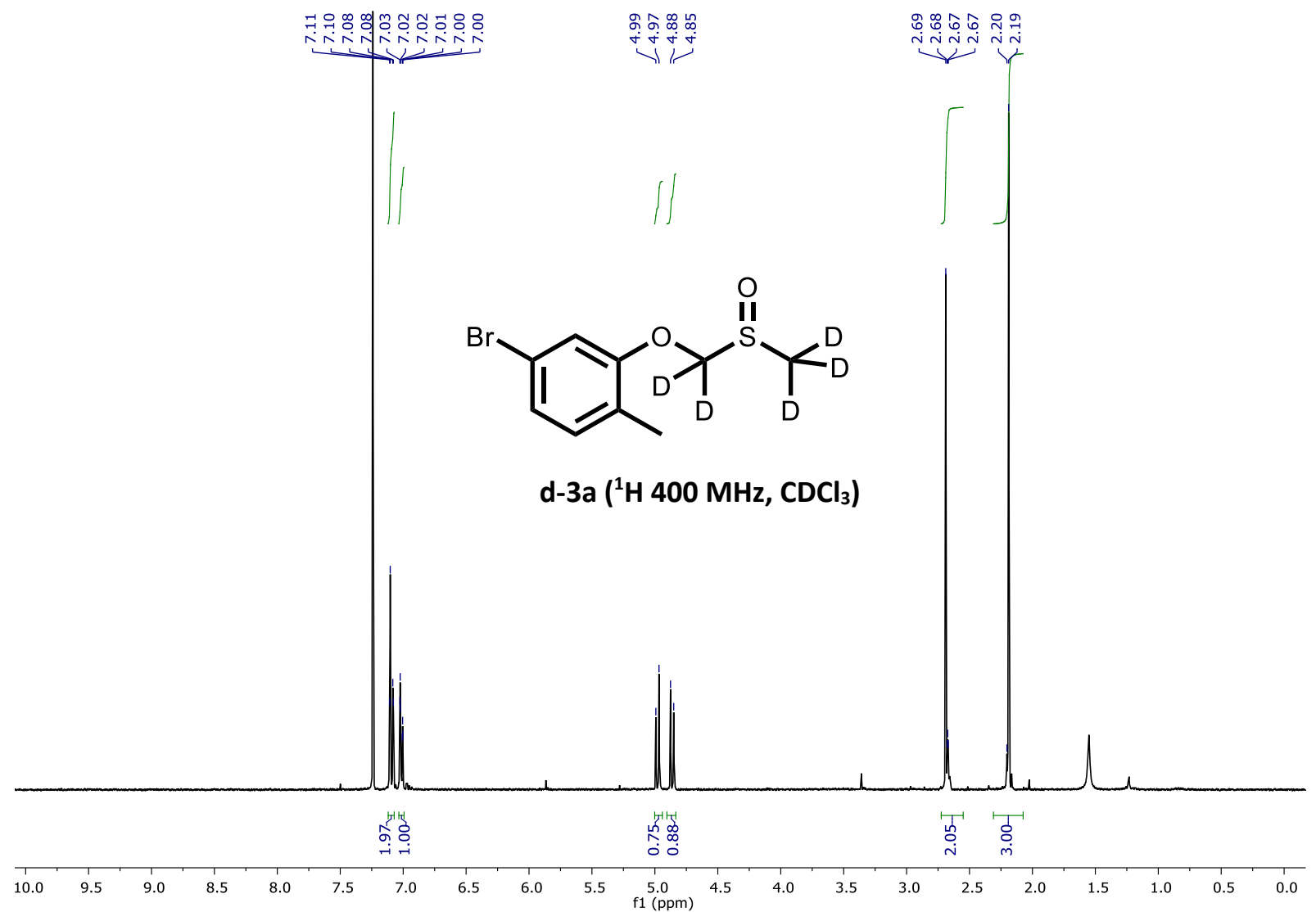




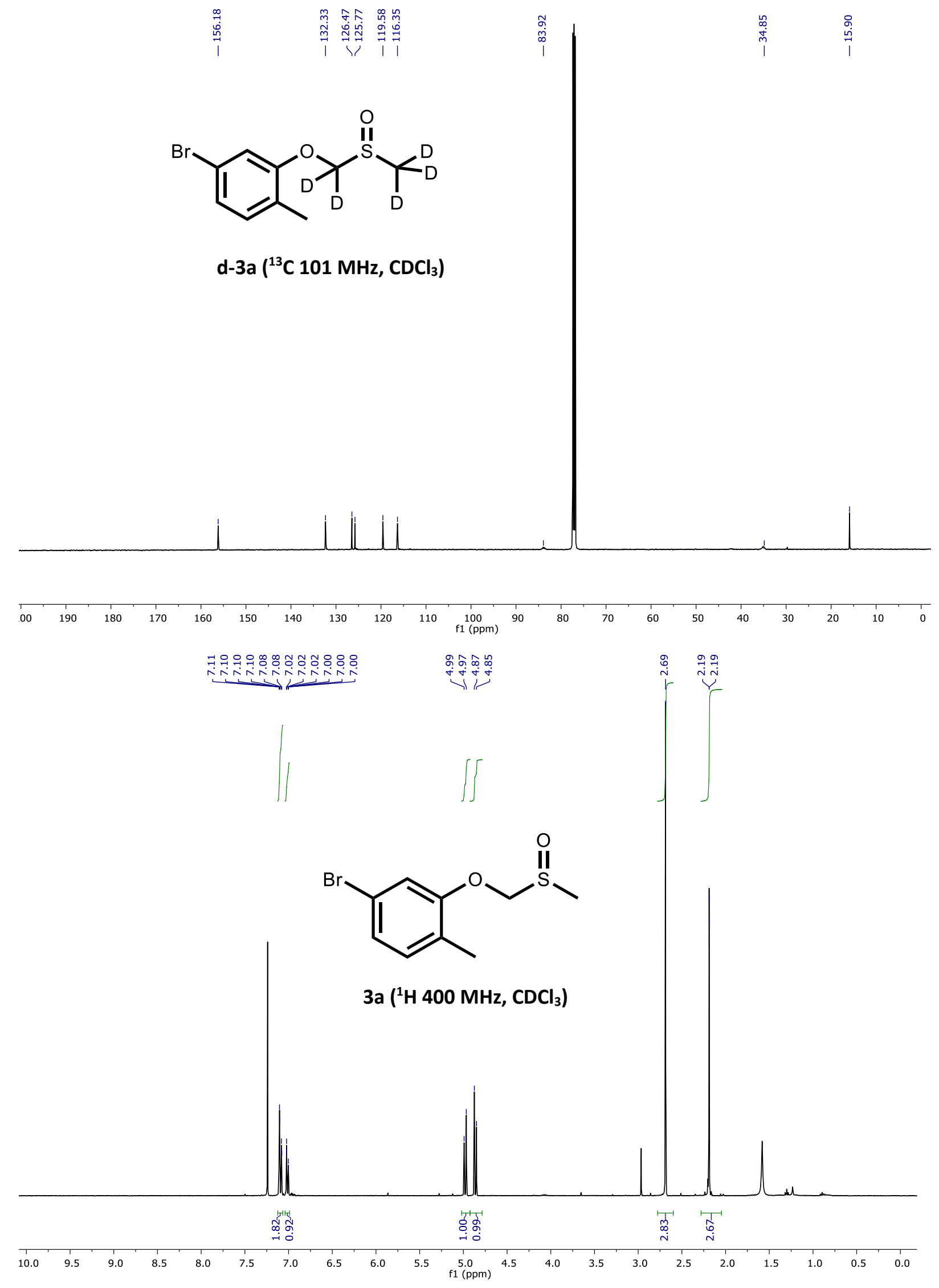




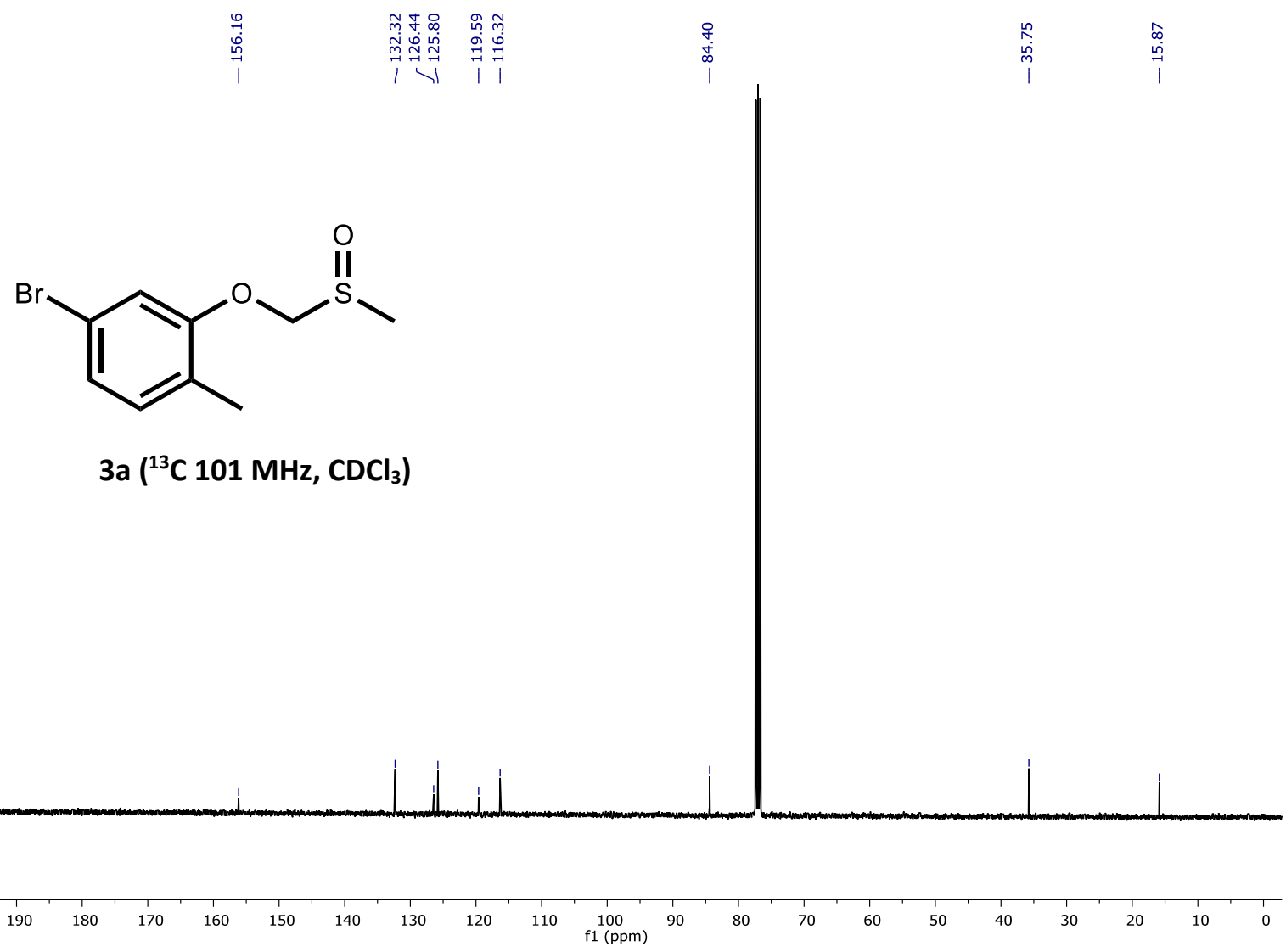



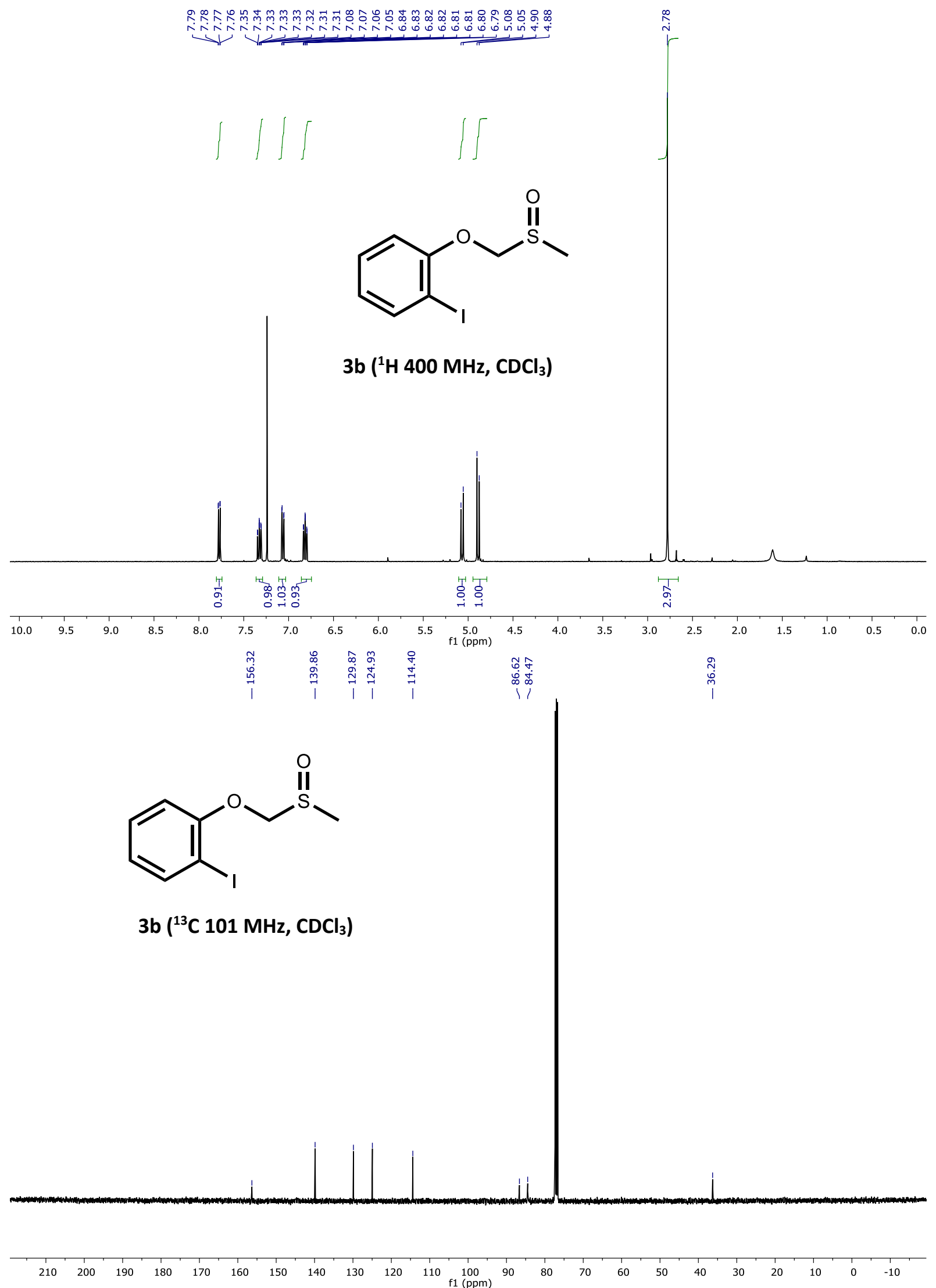

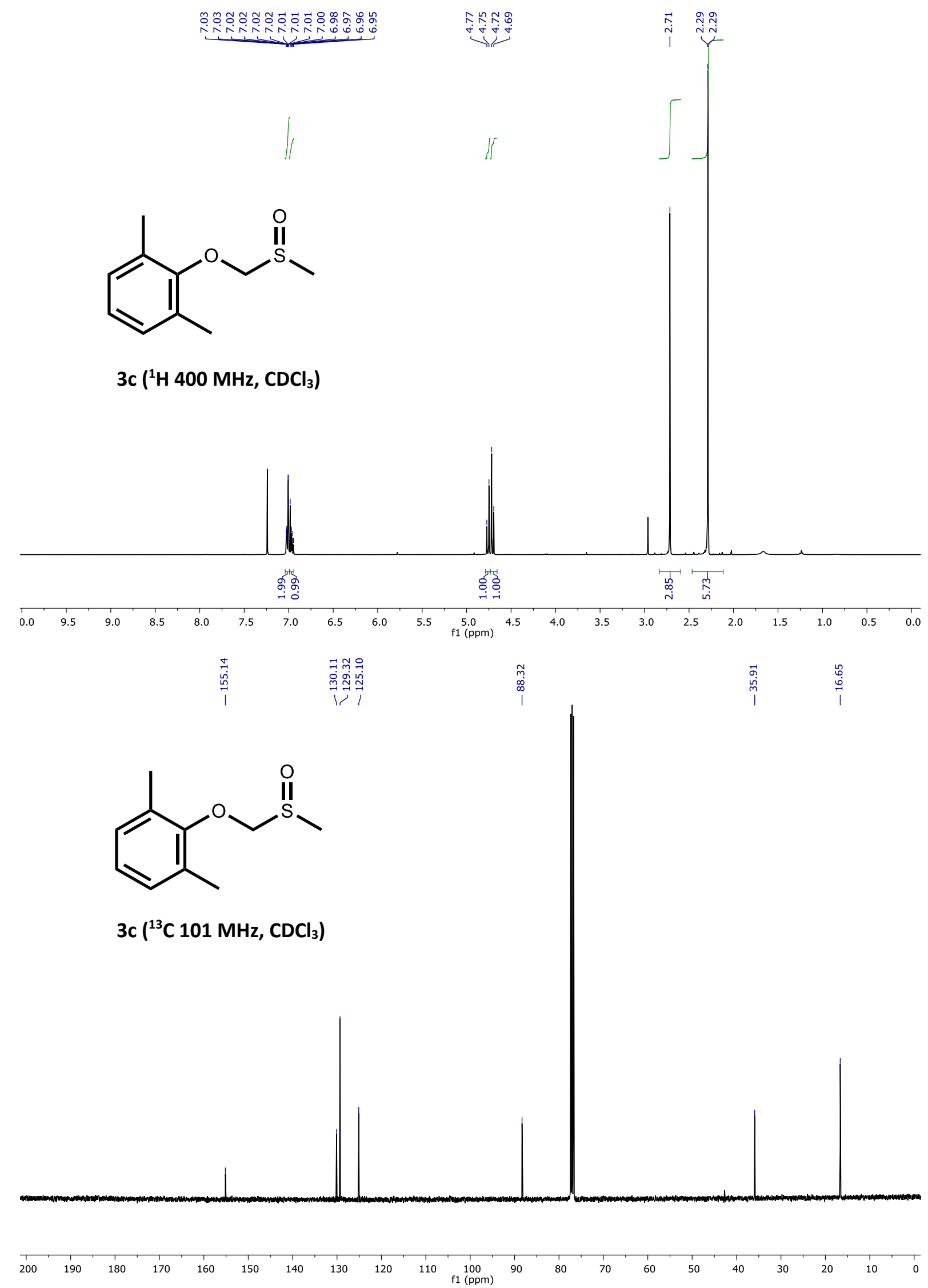

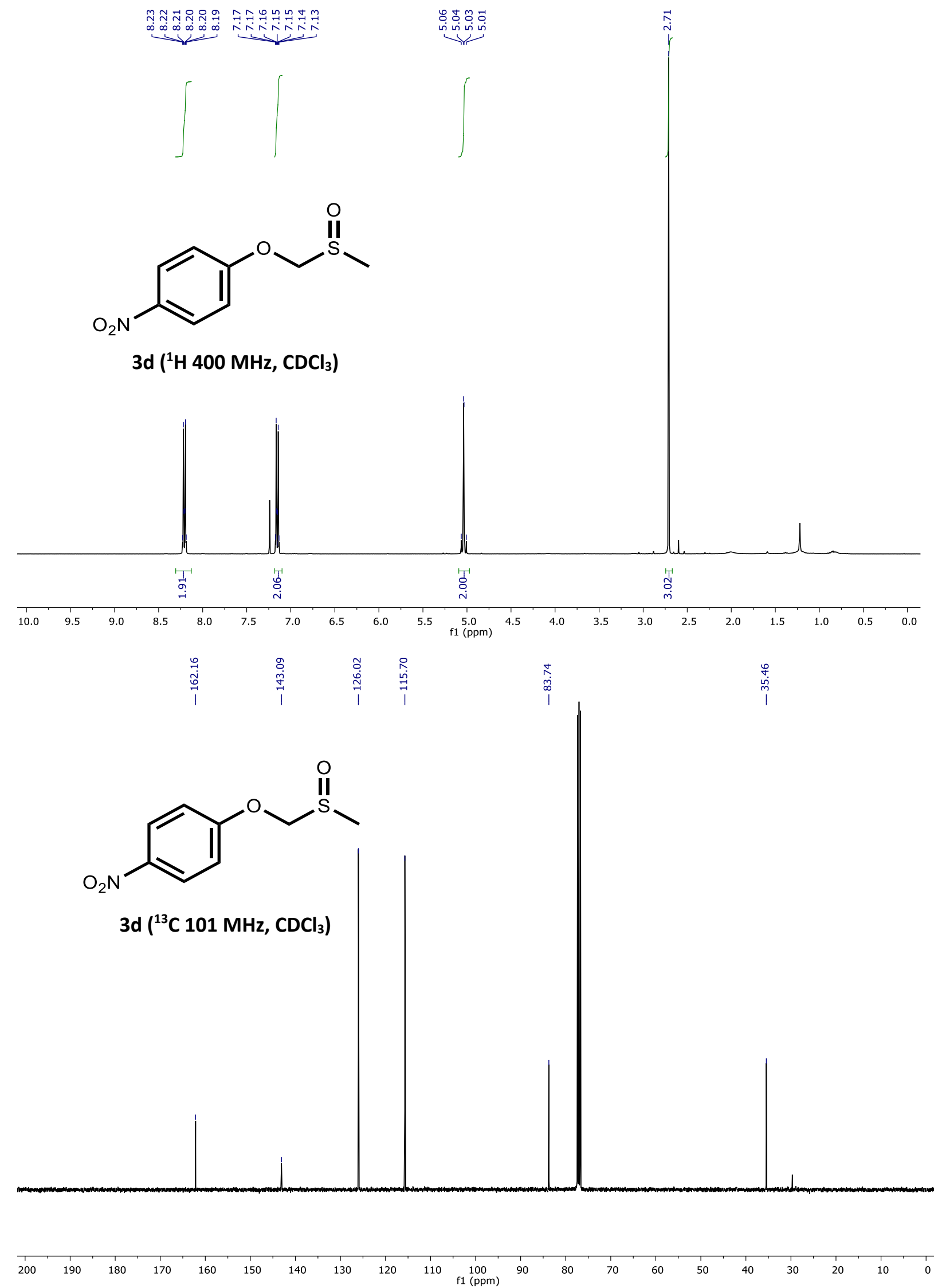


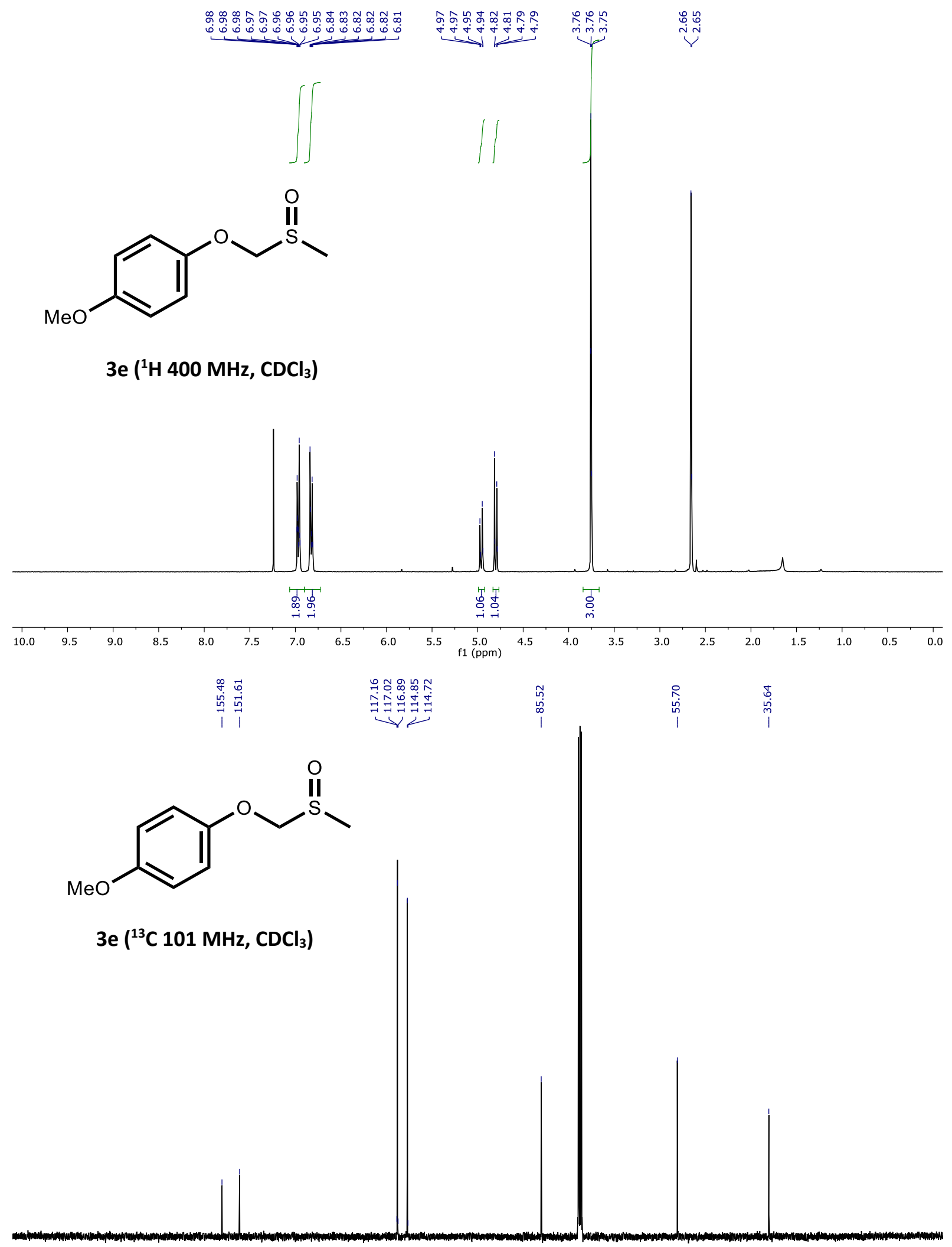

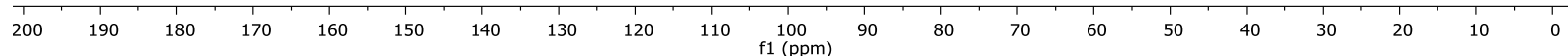




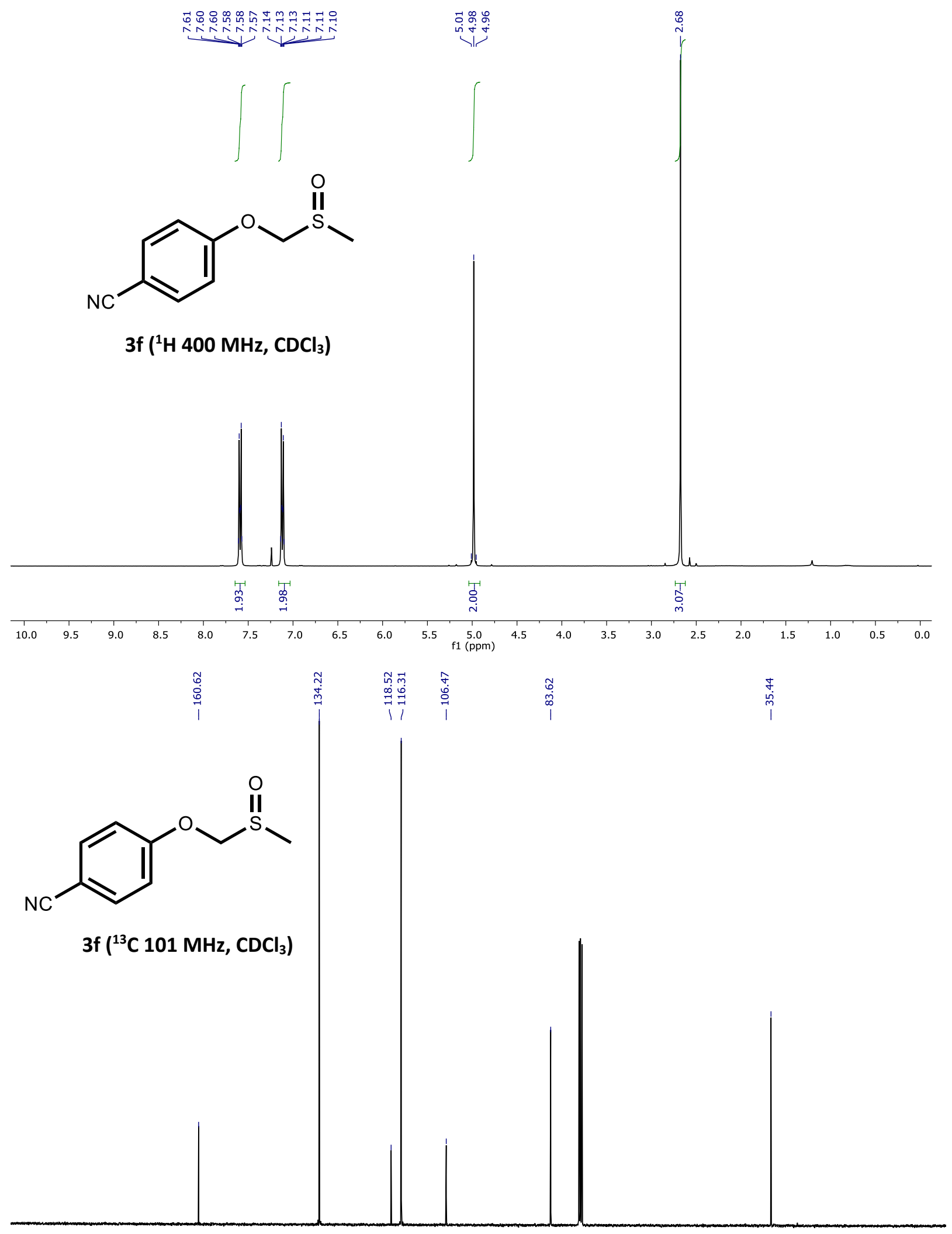

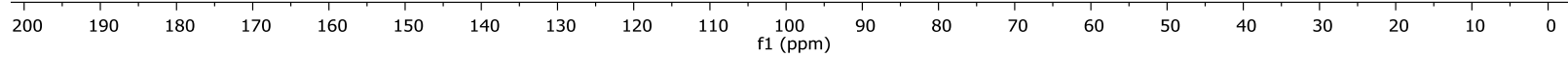




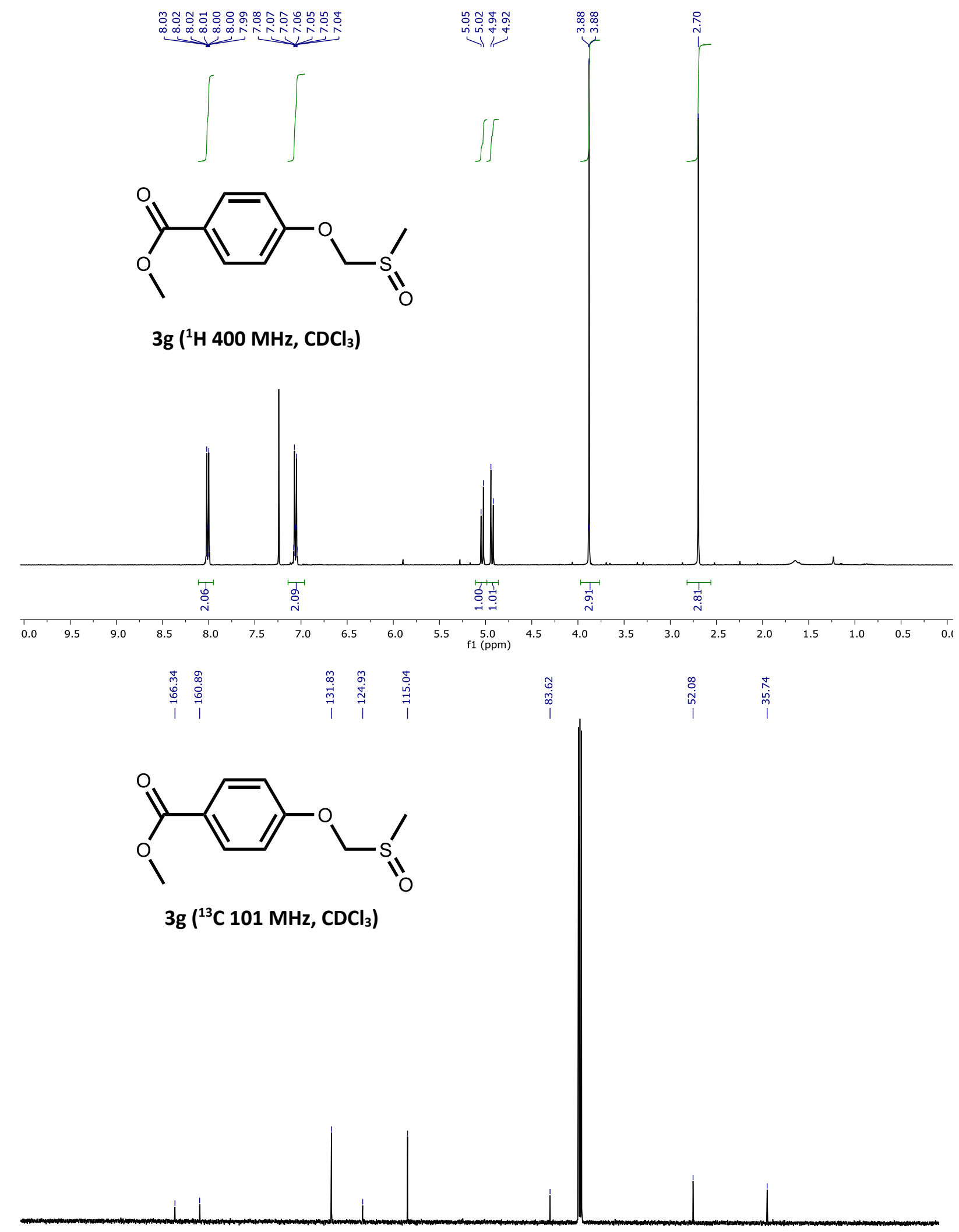

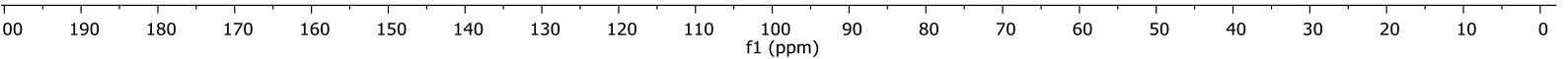



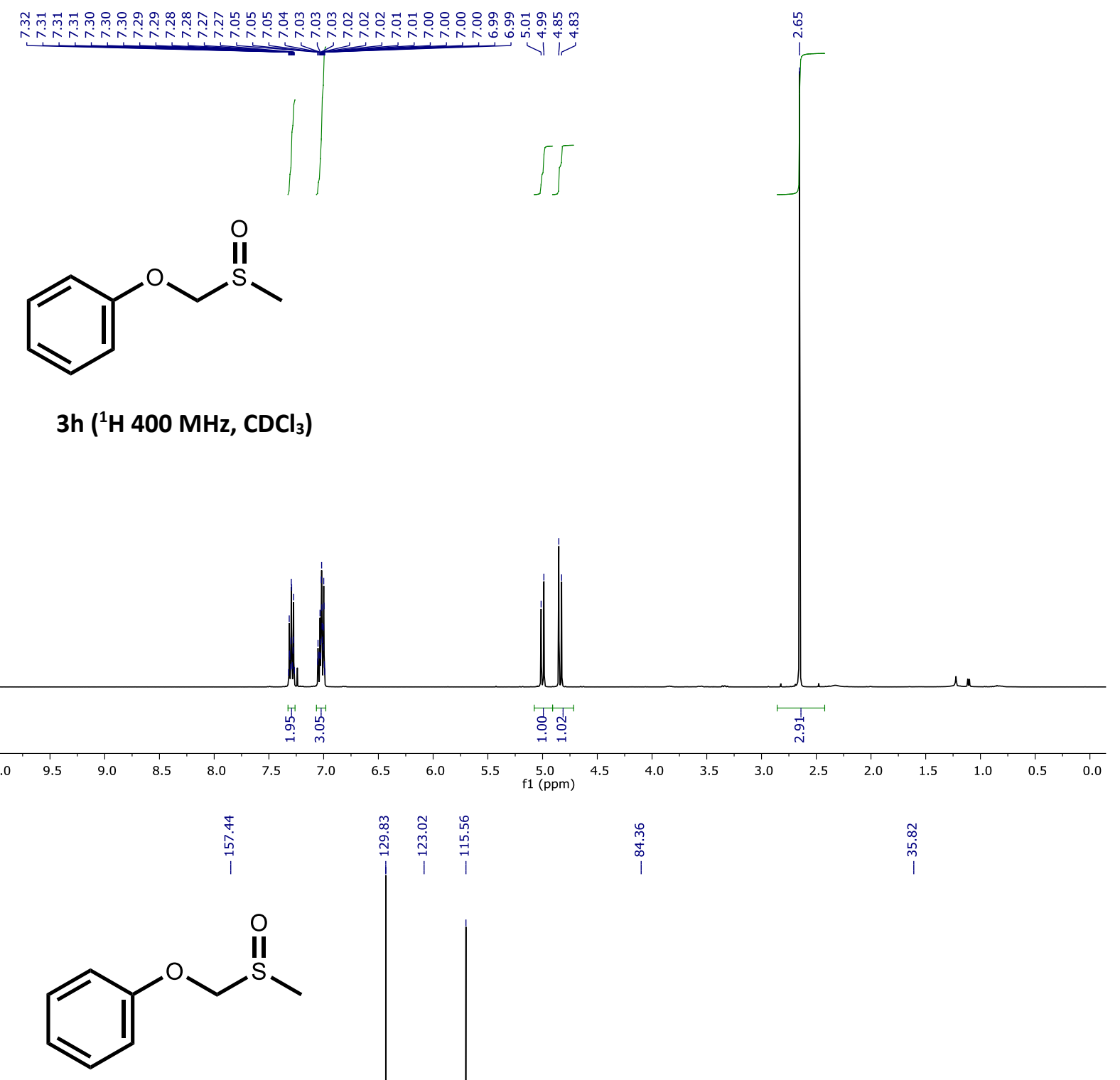

$3 \mathrm{~h}\left({ }^{13} \mathrm{C} 101 \mathrm{MHz}, \mathrm{CDCl}_{3}\right)$
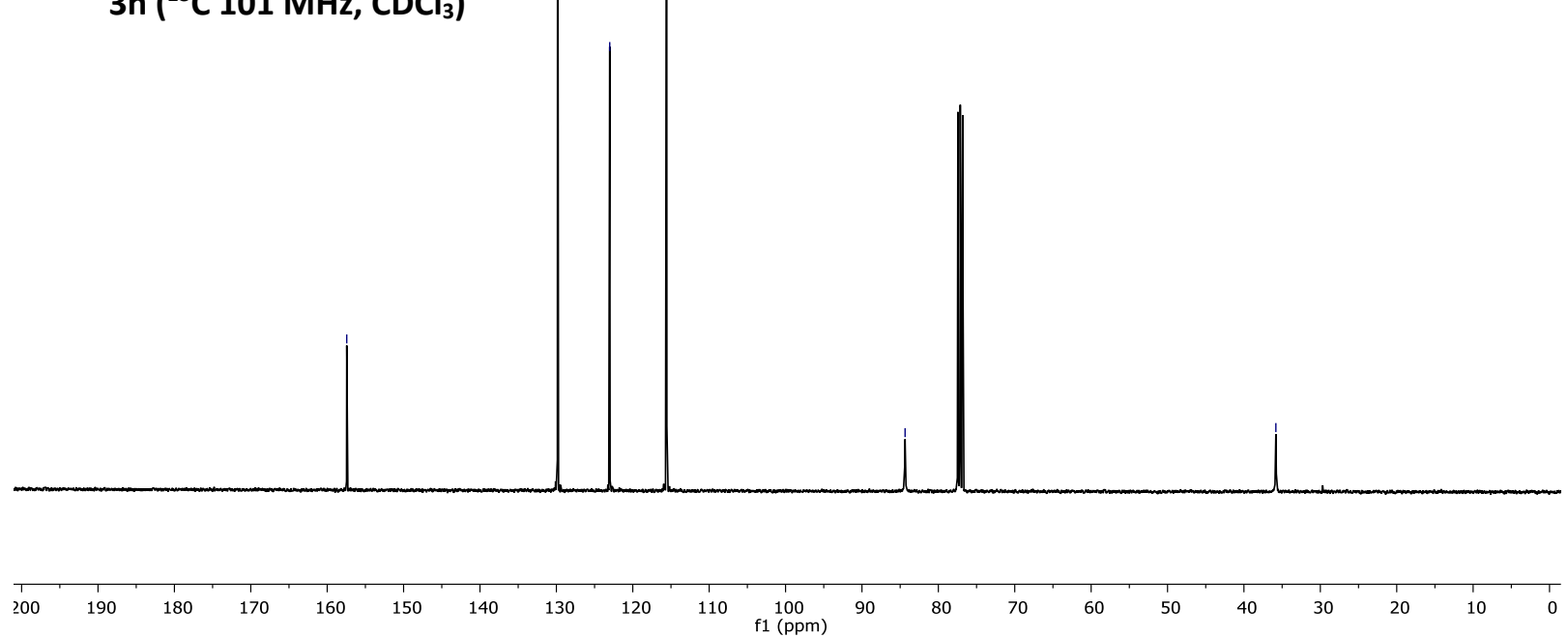

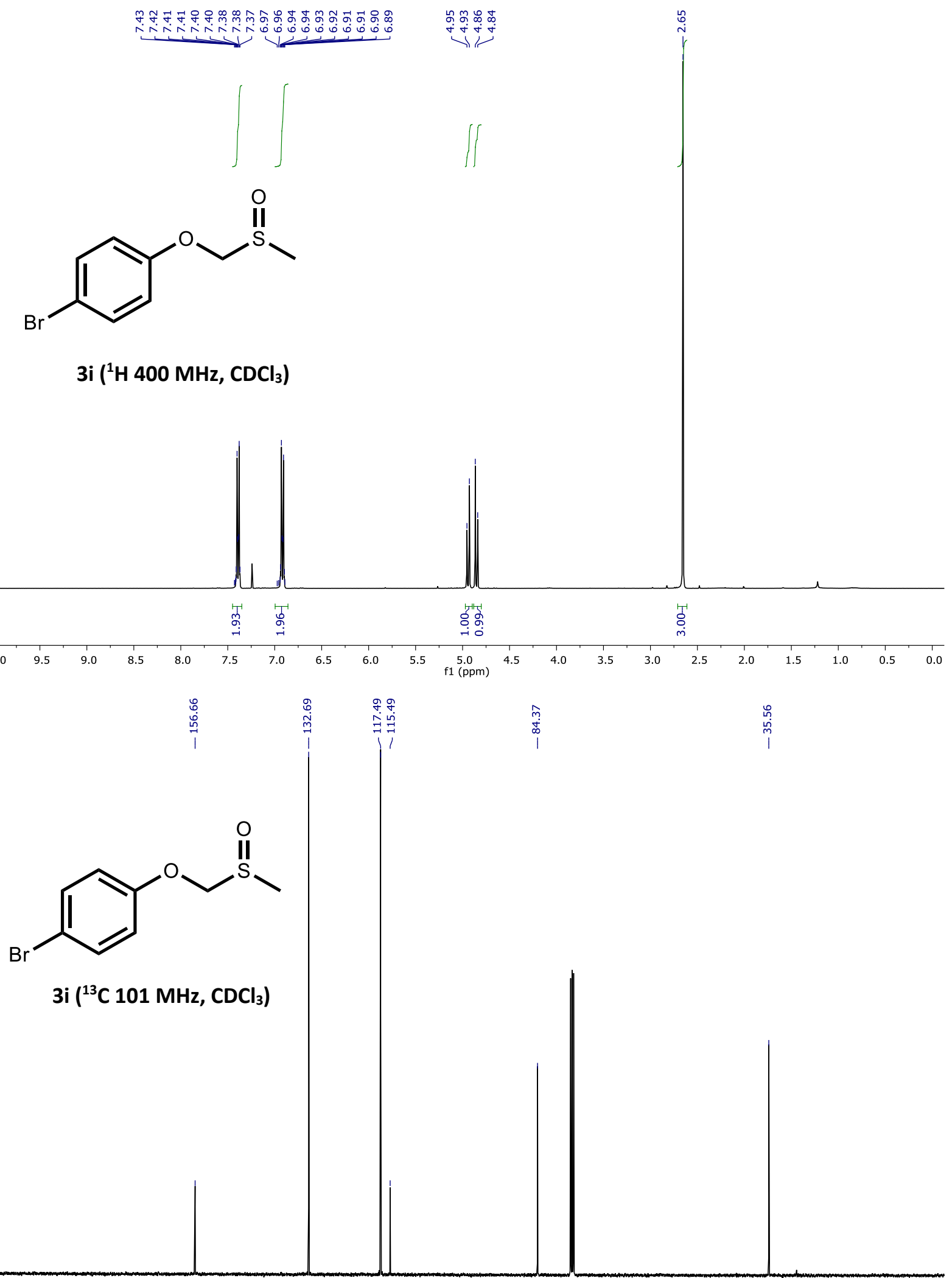

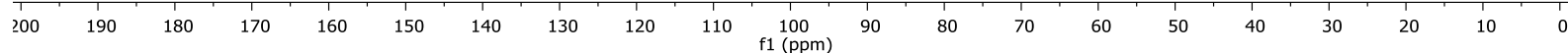



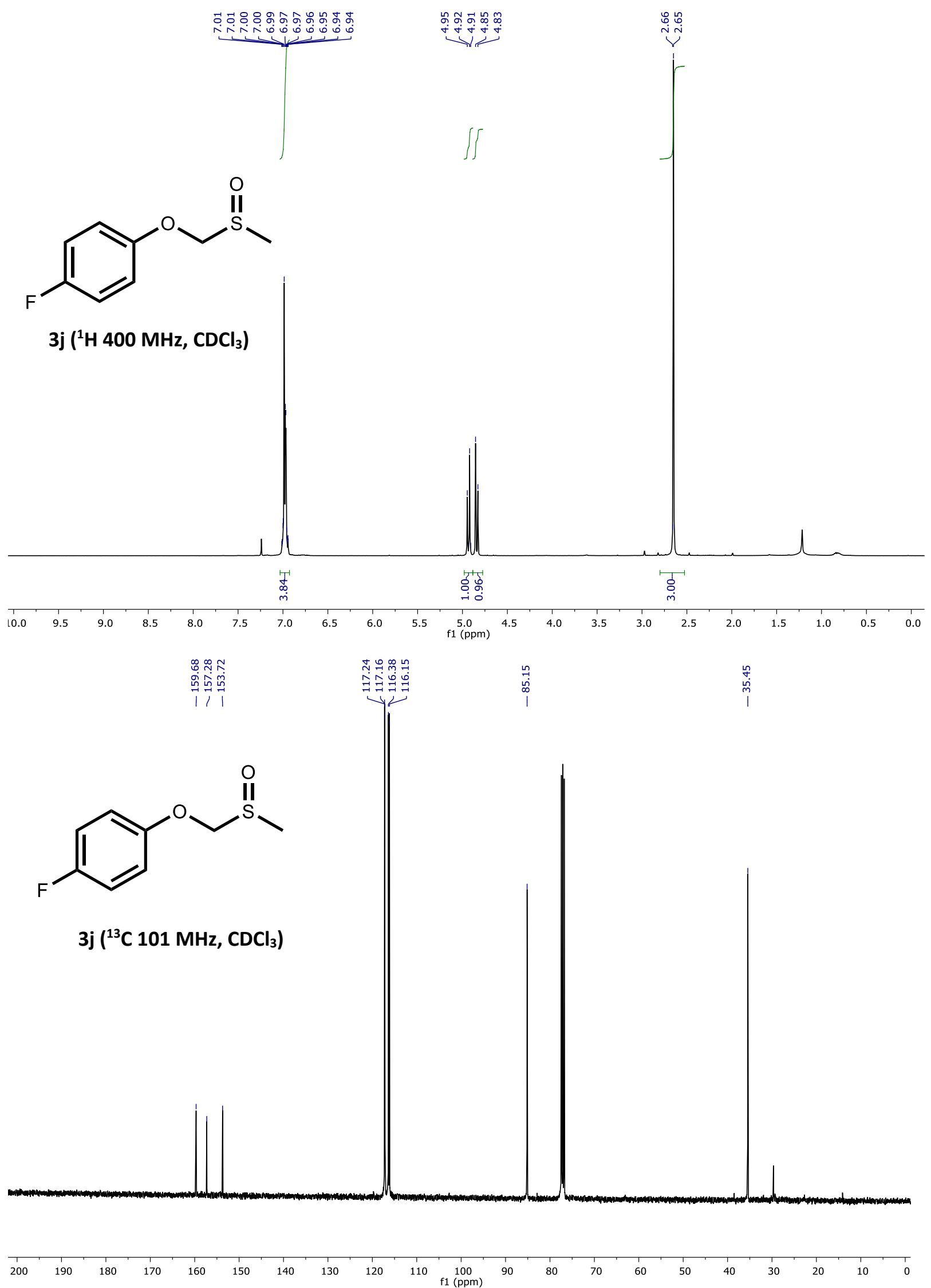


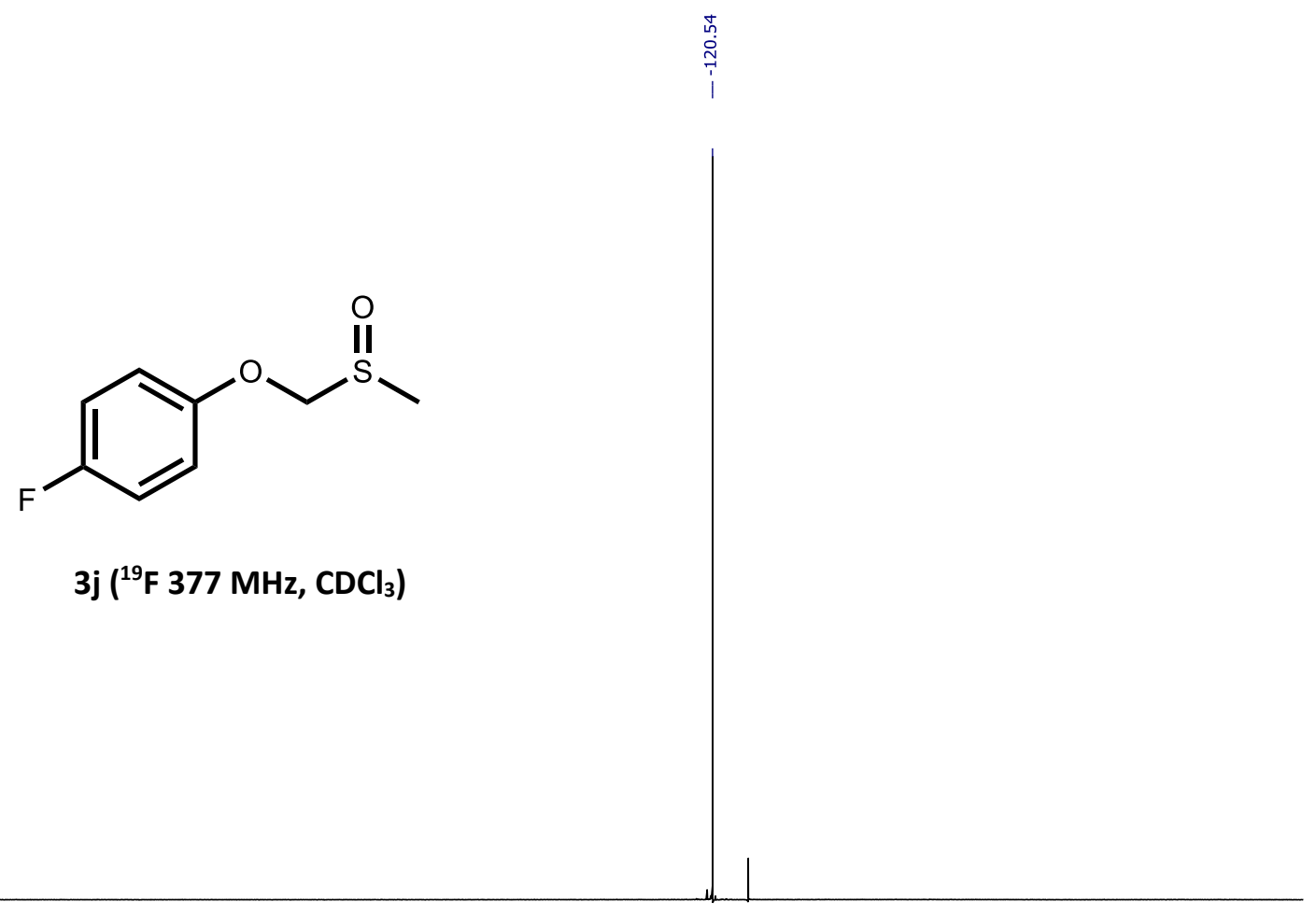

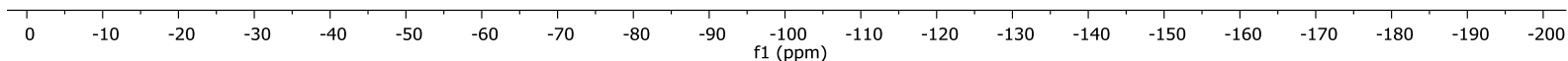




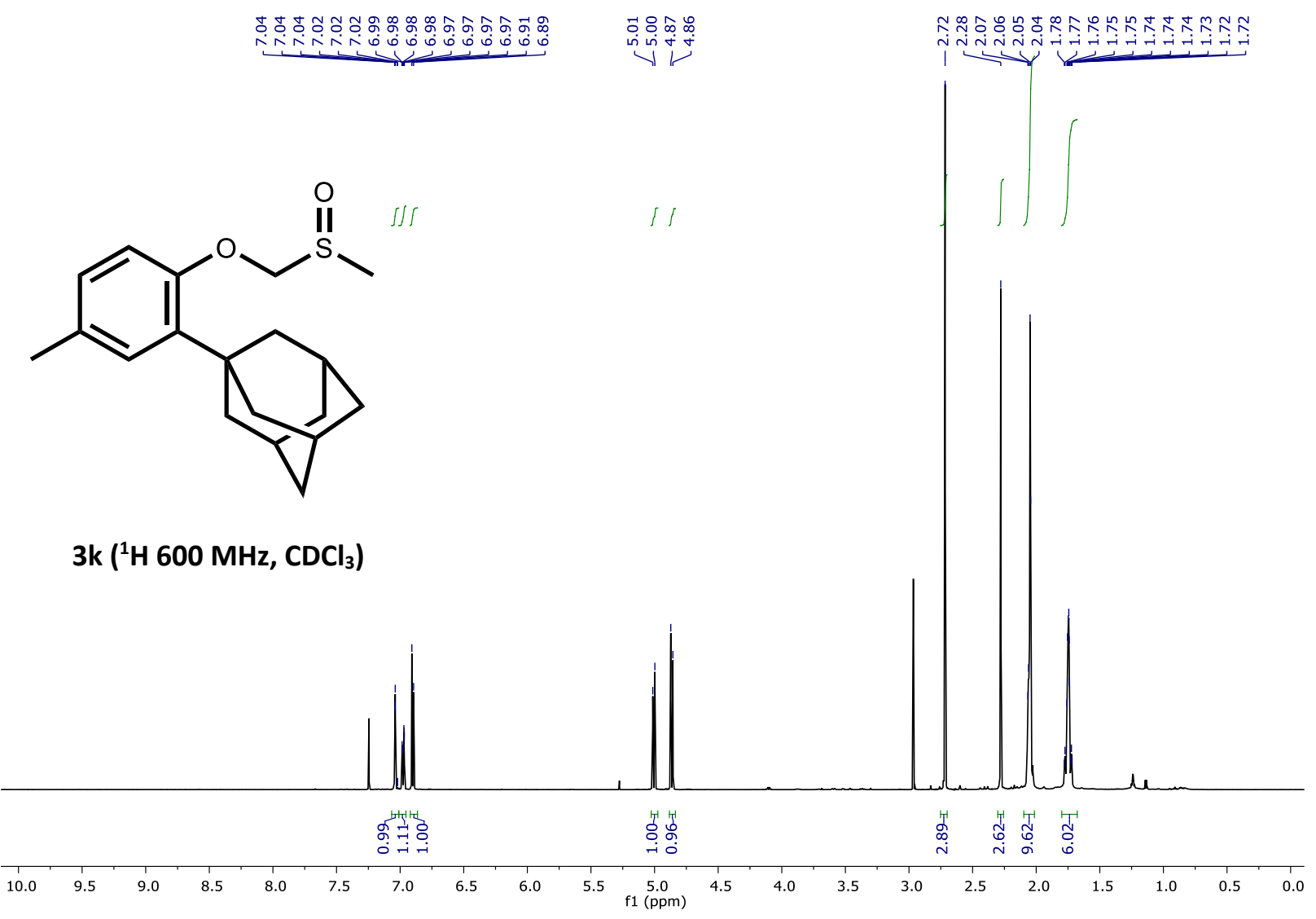

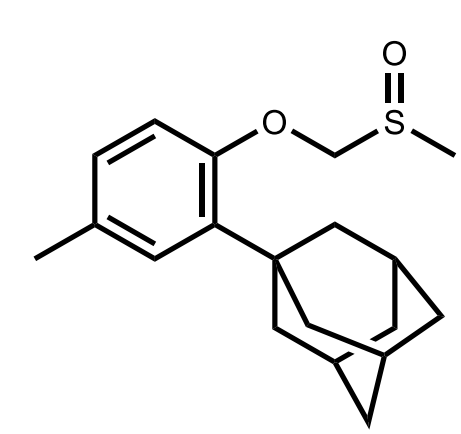

3k $\left({ }^{13} \mathrm{C} 151 \mathrm{MHz}, \mathrm{CDCl}_{3}\right)$

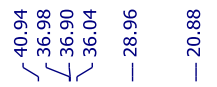

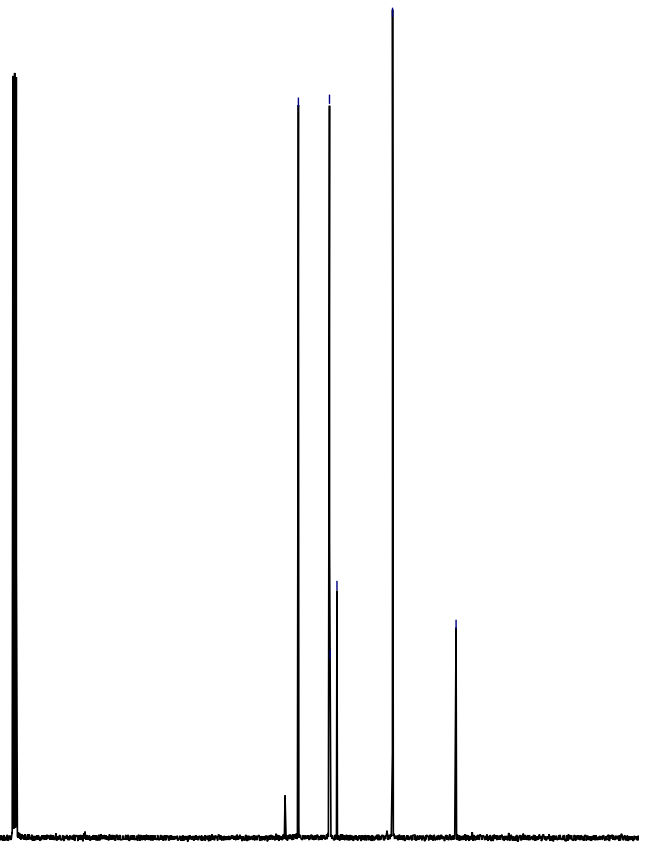

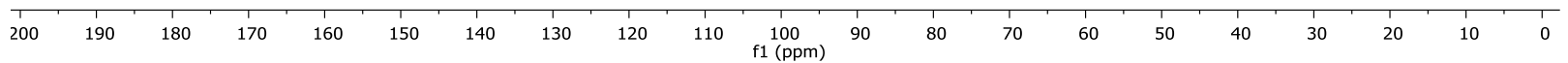



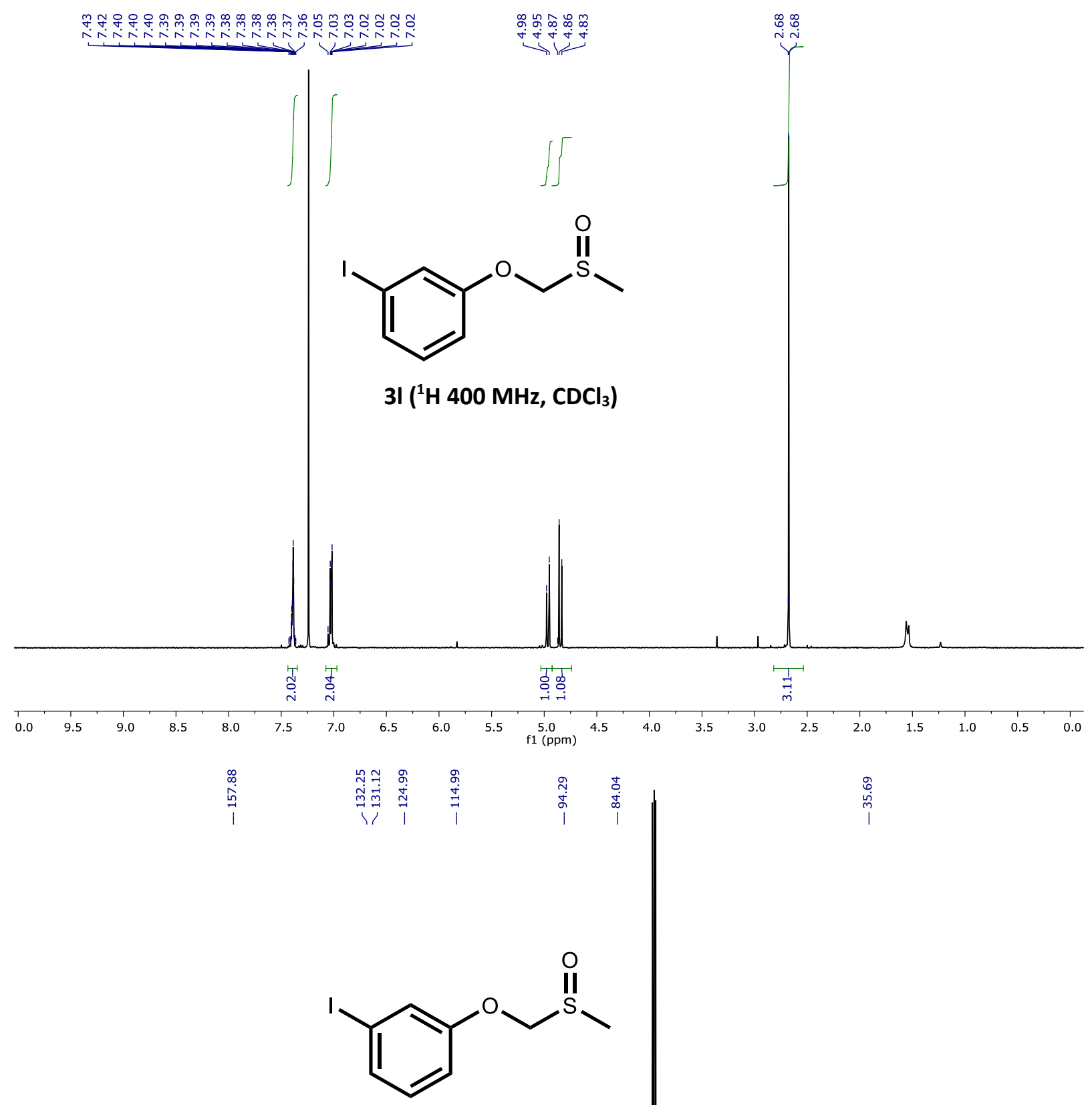

3I $\left({ }^{13} \mathrm{C} 101 \mathrm{MHz}, \mathrm{CDCl}_{3}\right)$

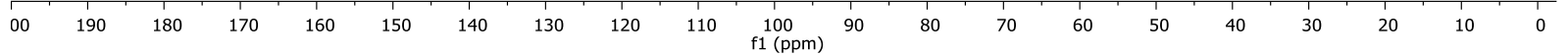




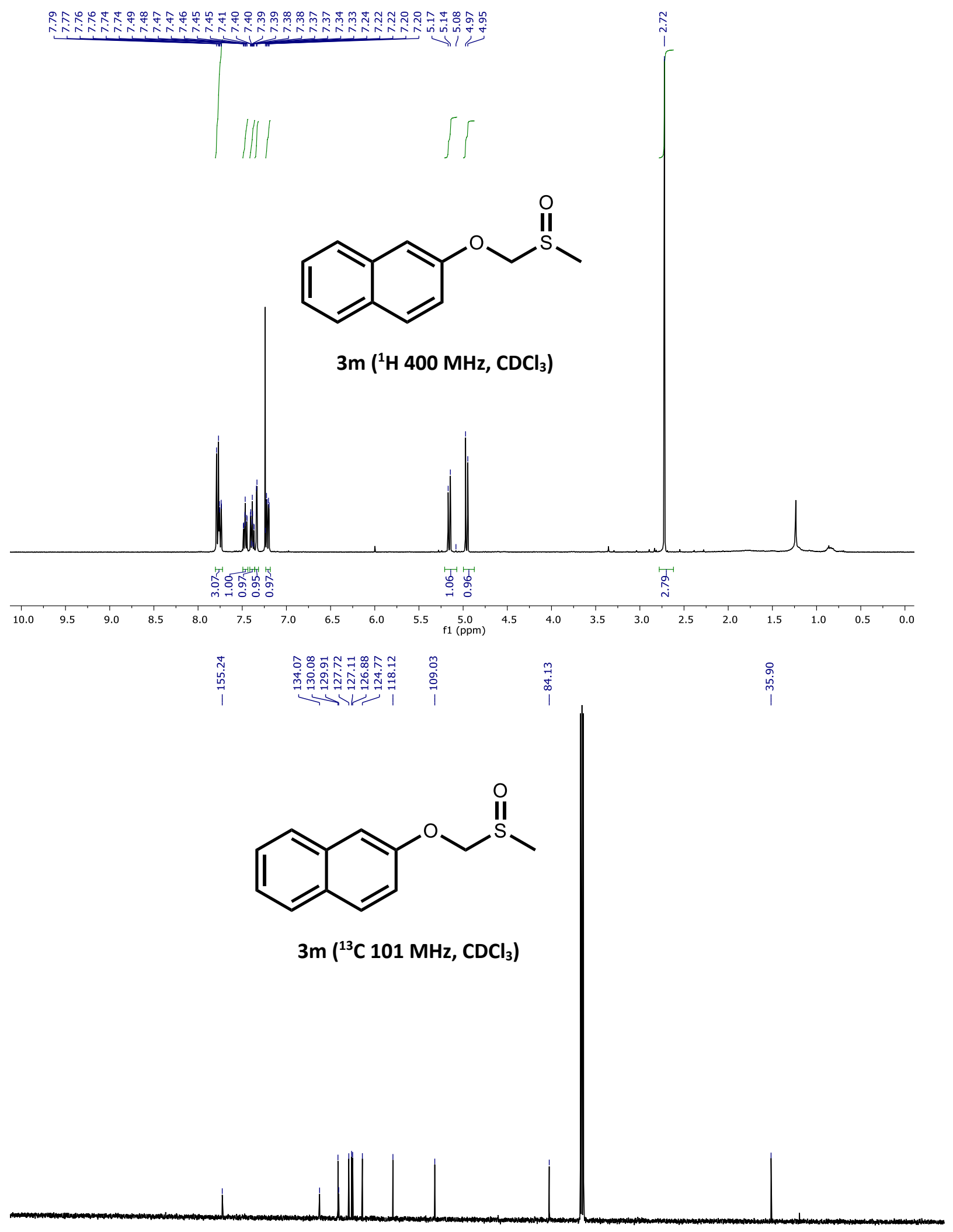

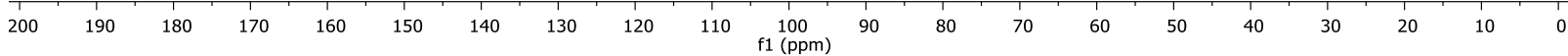




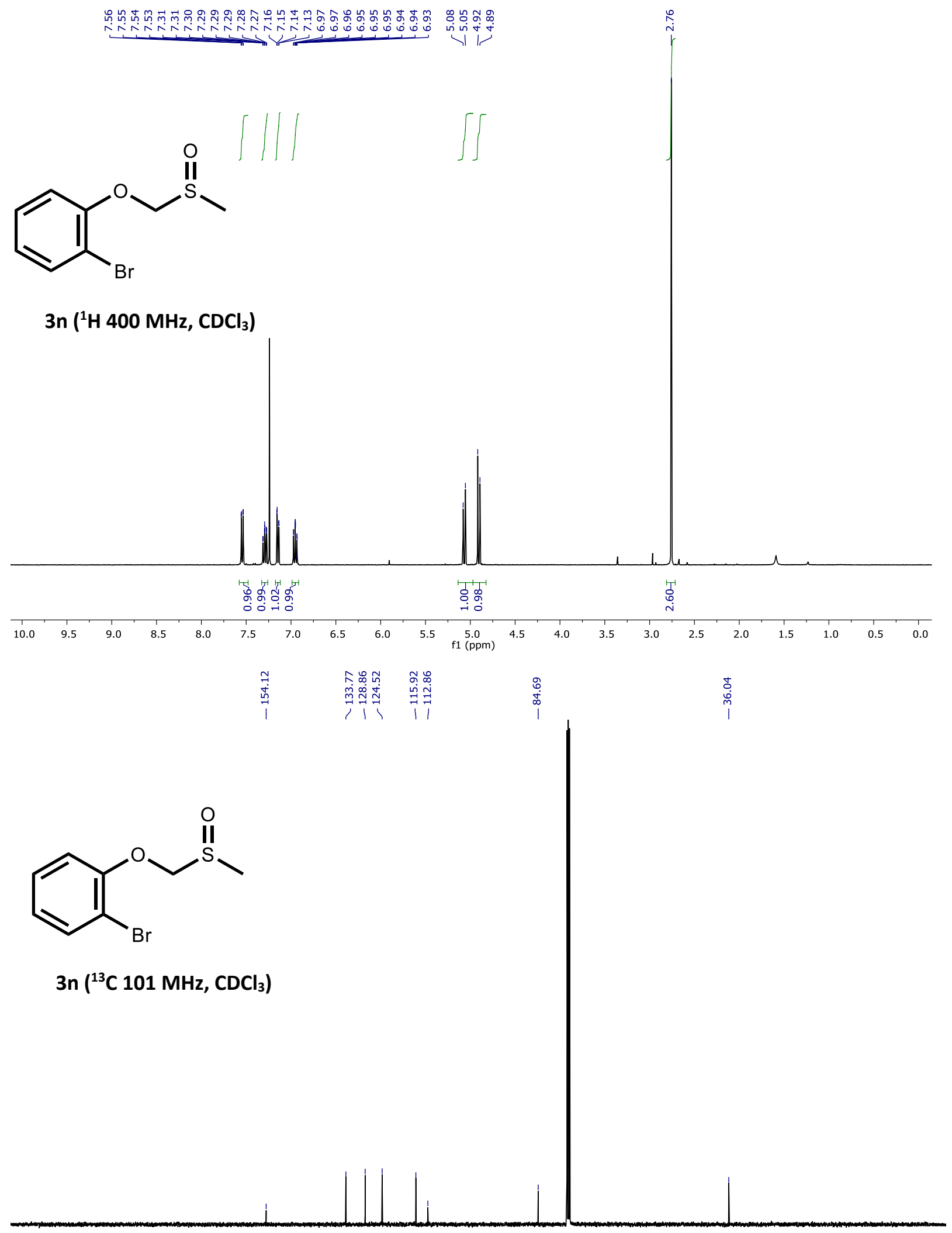

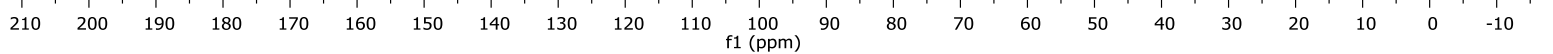



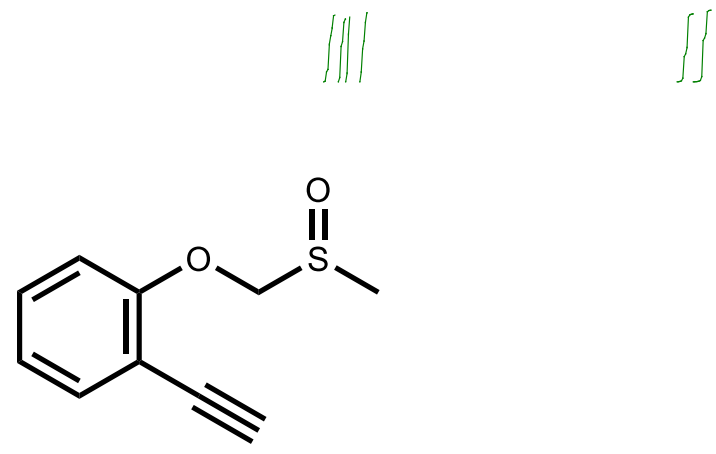

$30\left({ }^{1} \mathrm{H} 400 \mathrm{MHz}, \mathrm{CDCl}_{3}\right)$
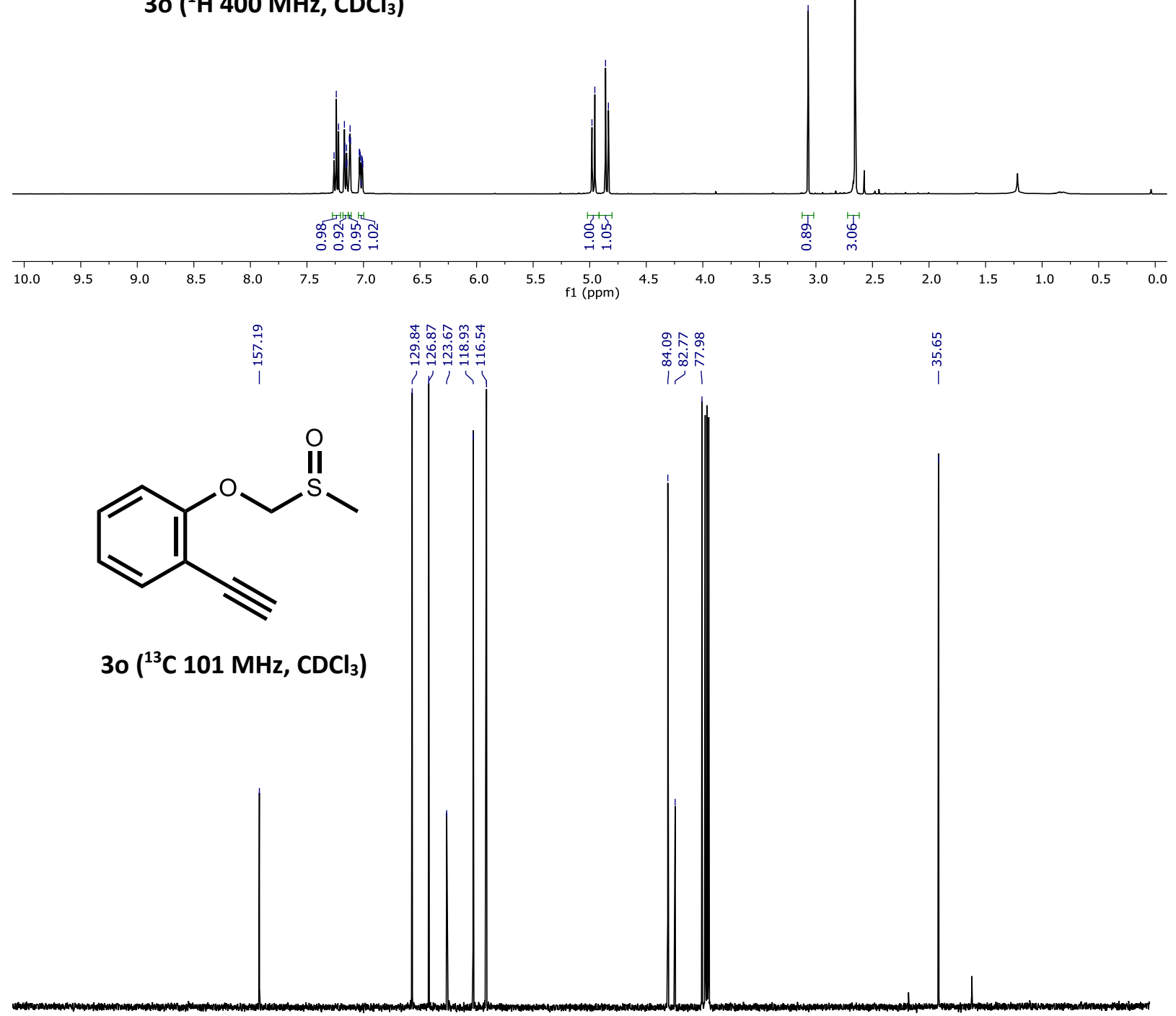

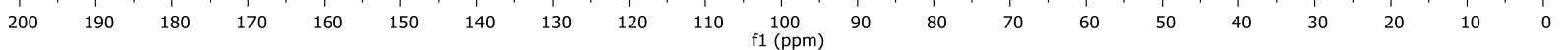



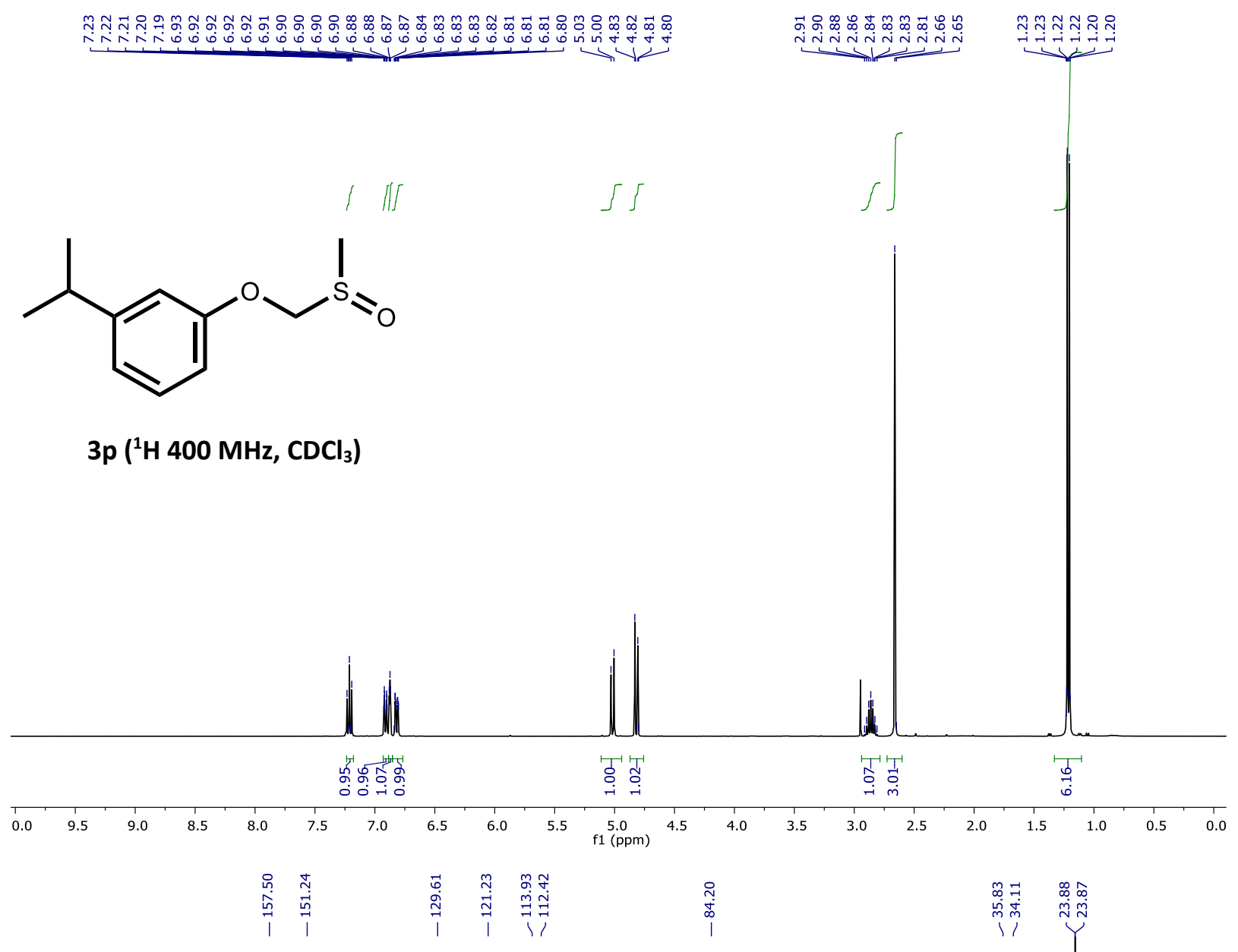<smiles>CC(C)c1cccc(OCS(C)=O)c1</smiles>

$3 p\left({ }^{13} \mathrm{C} 101 \mathrm{MHz}, \mathrm{CDCl}_{3}\right)$

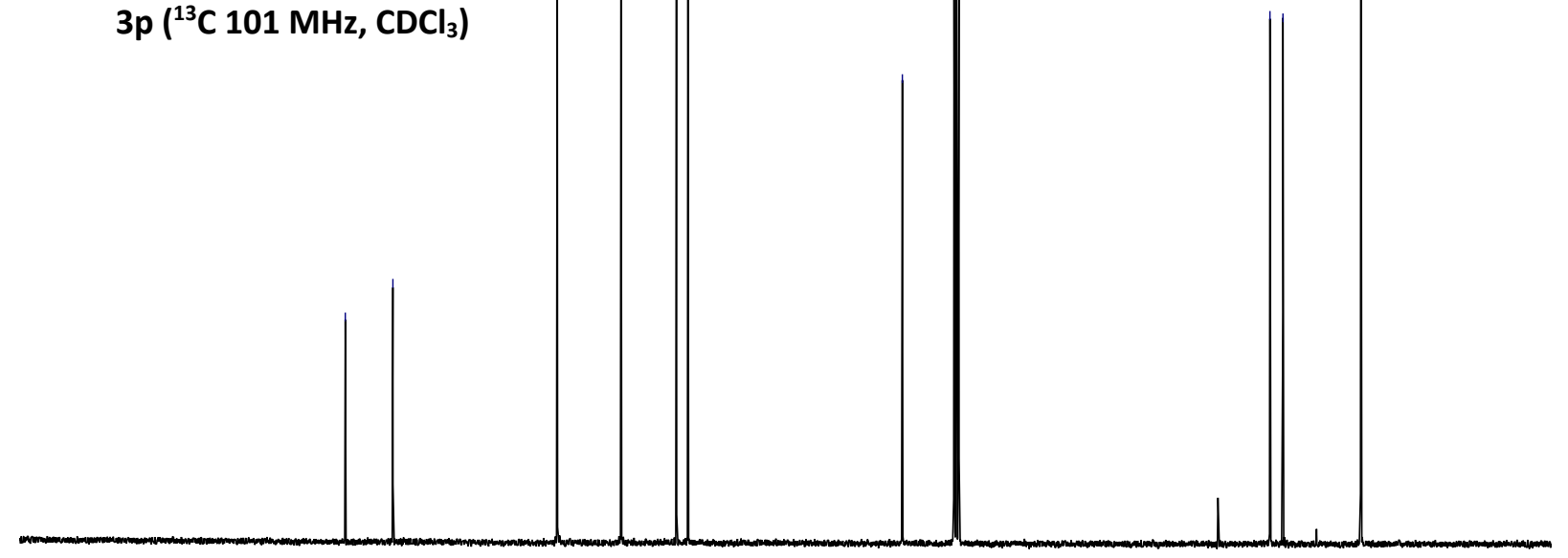

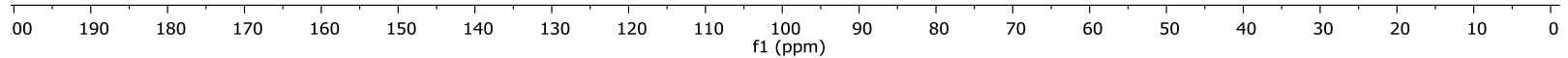




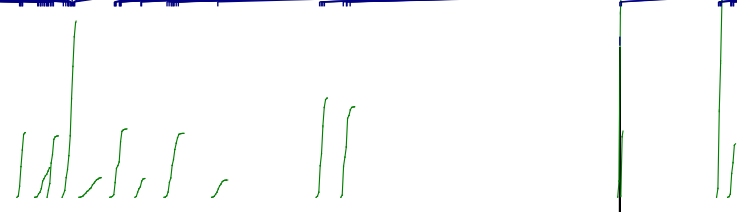<smiles>CC=Cc1ccccc1OCS(C)=O</smiles>

$3 q\left({ }^{1} \mathrm{H} 400 \mathrm{MHz}, \mathrm{CDCl}_{3}\right)$

78:22 E:Z

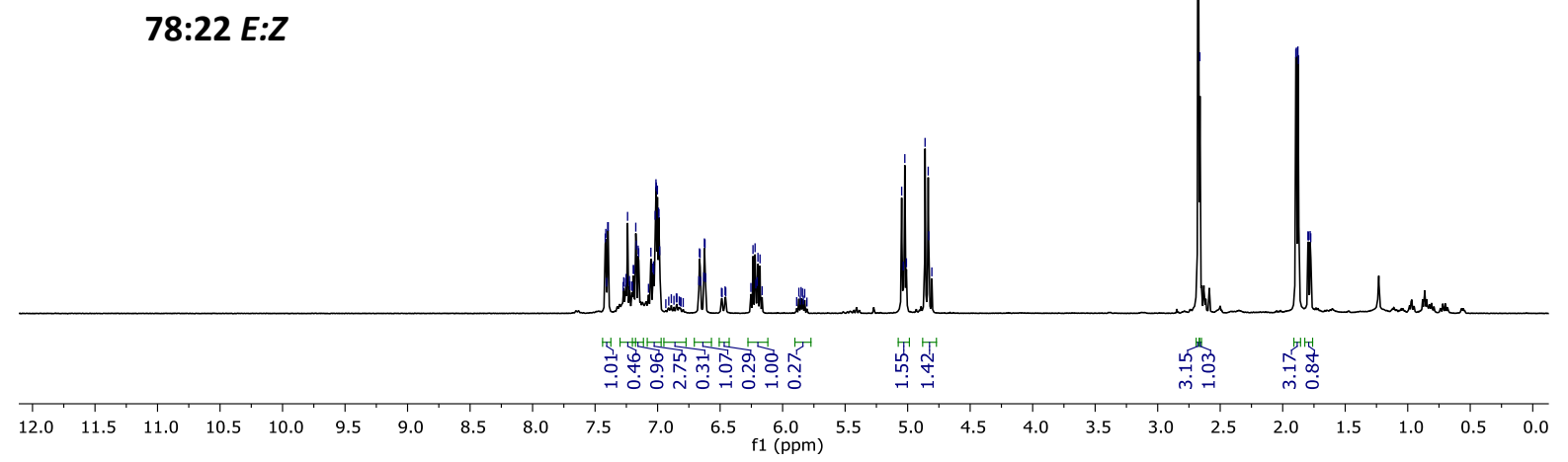

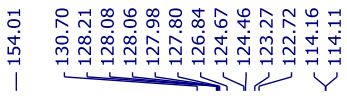

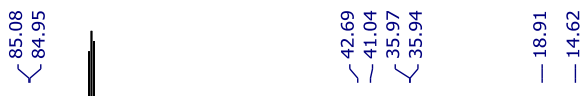<smiles>CC=Cc1ccccc1OCS(C)=O</smiles>

3q $\left({ }^{13} \mathrm{C} 101 \mathrm{MHz}, \mathrm{CDCl}_{3}\right)$

78:22 E:Z

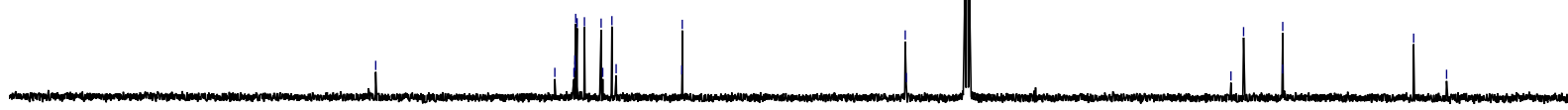




\section{$\underbrace{9} \underbrace{9}$}
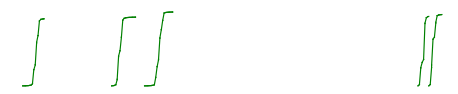<smiles>CS(=O)COc1c(F)cccc1Br</smiles>

$3 r\left({ }^{1} \mathrm{H} 400 \mathrm{MHz}, \mathrm{CDCl}_{3}\right)$

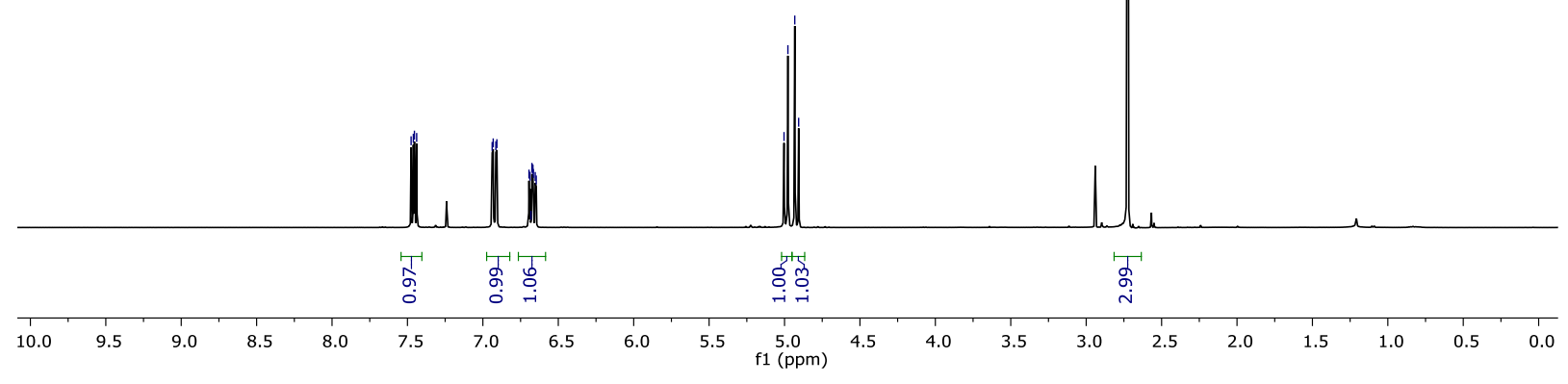

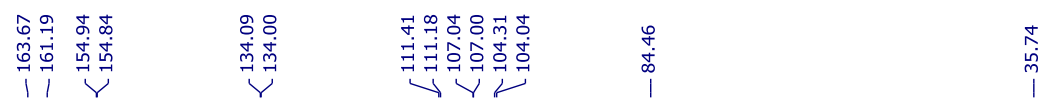

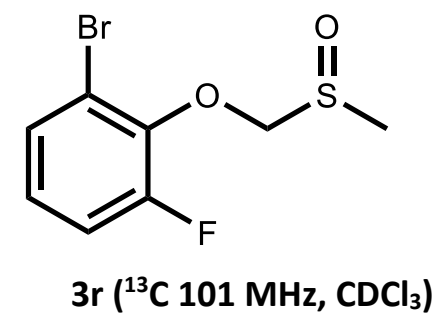

$200 \quad 190 \quad 180 \quad 170 \quad 160 \quad 150 \quad 140$
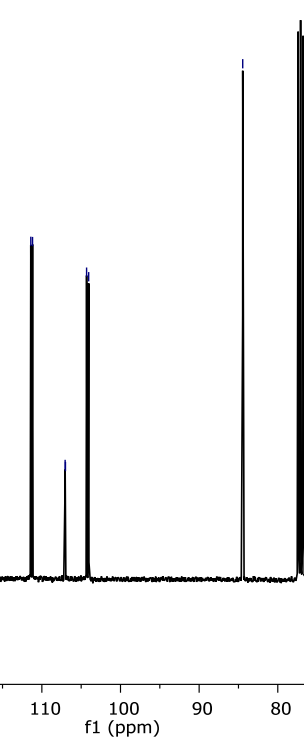

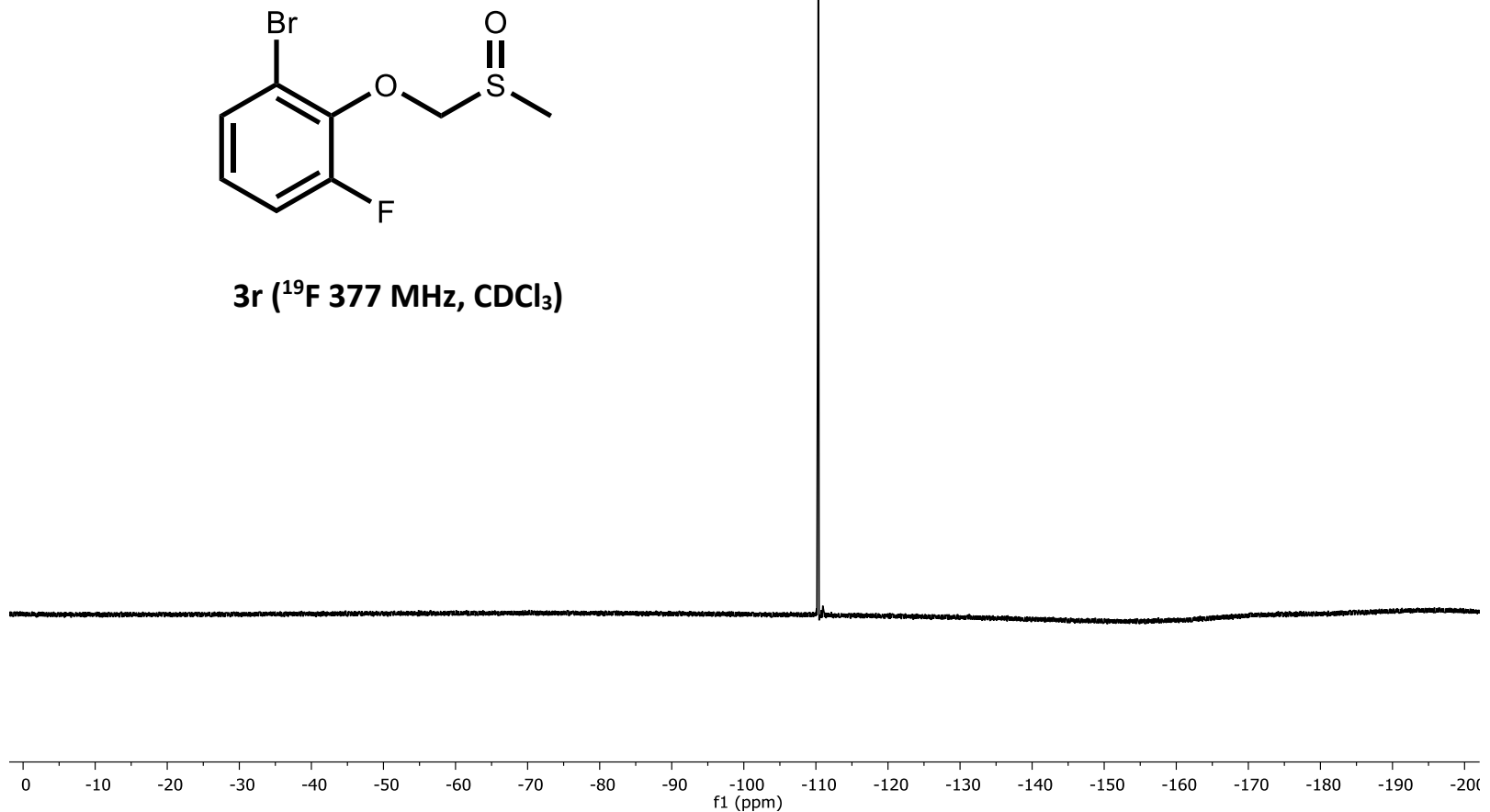

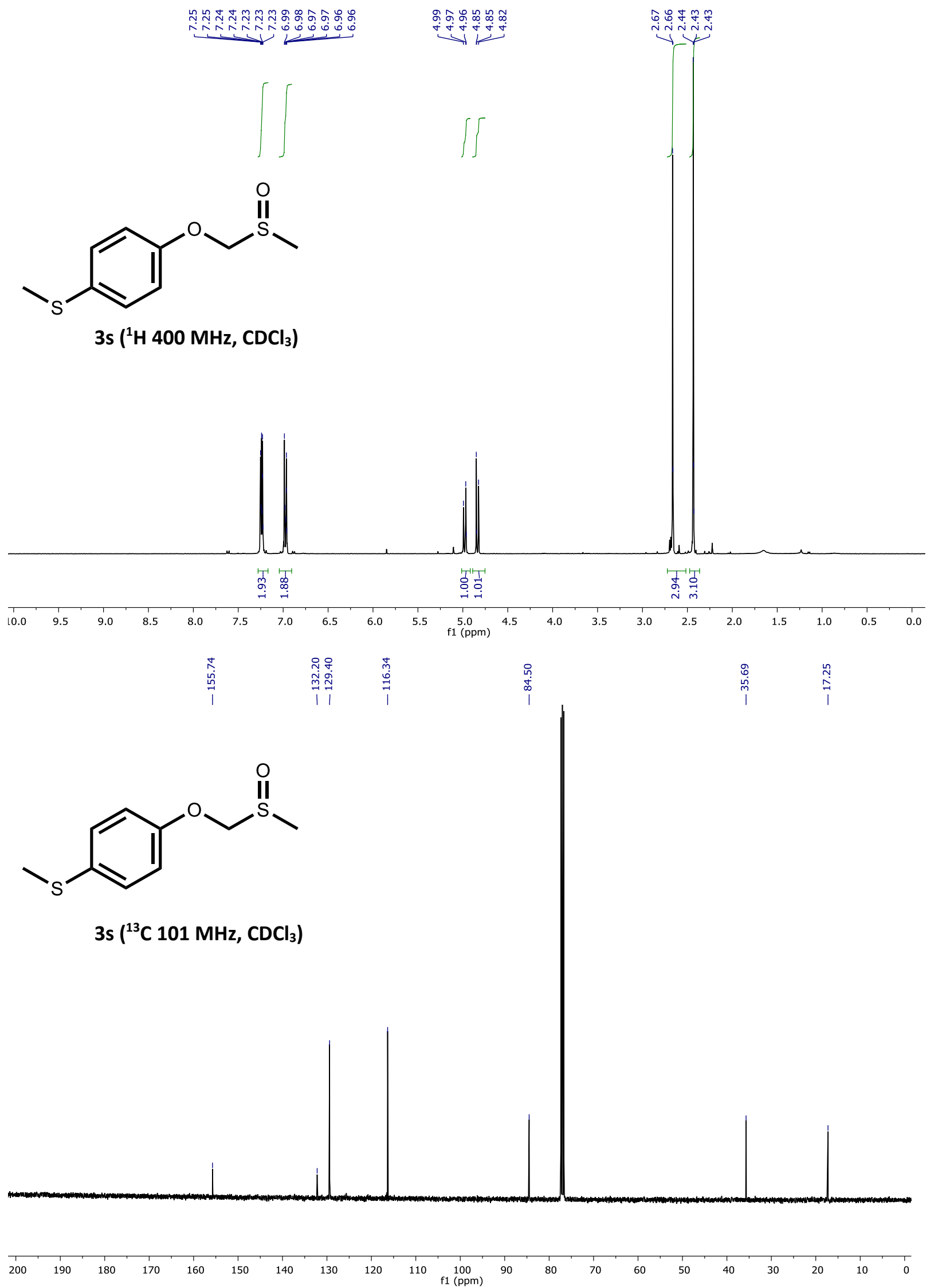


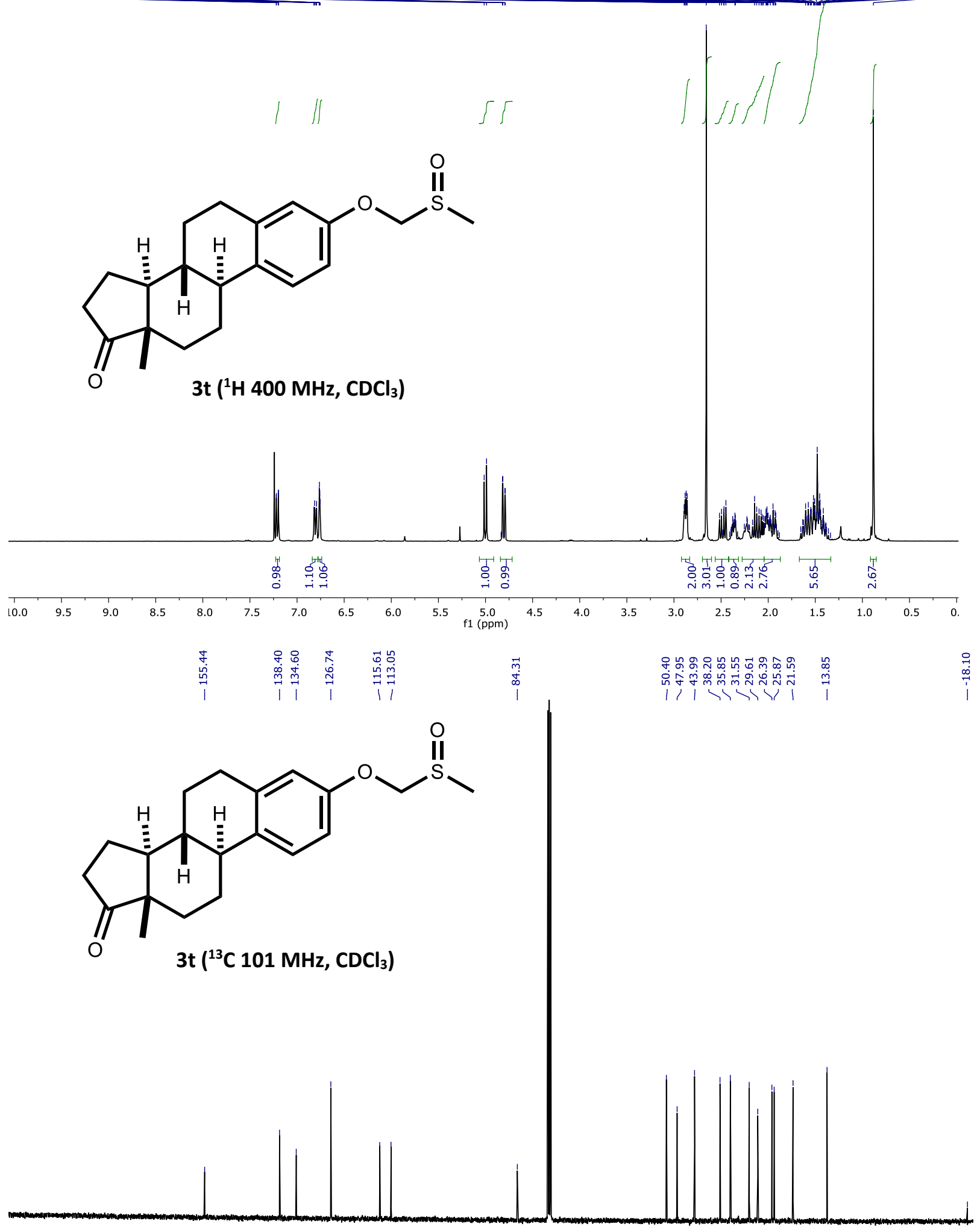

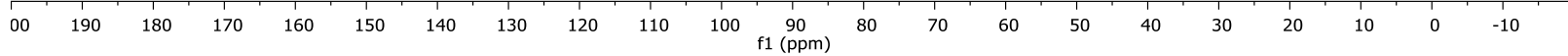


<smiles>Cc1c(C)c2c(c(C)c1OCS(C)=O)CC[C@@](C)(CCC[C@H](C)CCC[C@H](C)CCCC(C)C)O2</smiles>

3u ( $\left.{ }^{1} \mathrm{H} 400 \mathrm{MHz}, \mathrm{CDCl}_{3}\right)$

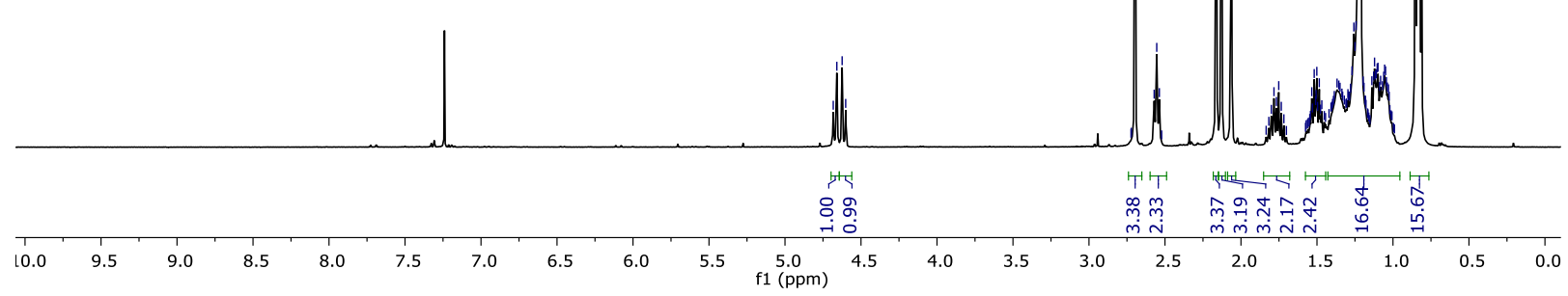

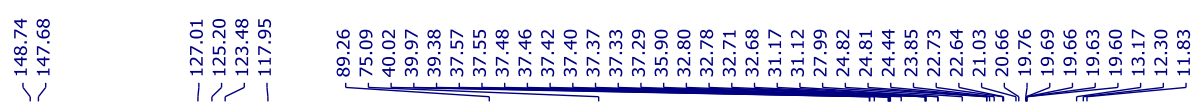<smiles>Cc1c(C)c2c(c(C)c1OCS(C)=O)CC[C@@](C)(CCC[C@H](C)CCC[C@H](C)CCCC(C)C)O2</smiles>

$3 \mathrm{u}\left({ }^{13} \mathrm{C} 101 \mathrm{MHz}, \mathrm{CDCl}_{3}\right)$

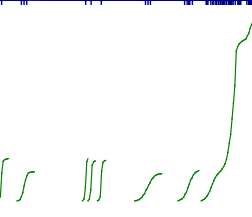

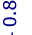

